\title{
The Privy Council appeal as a minority safeguard for the Protestant community of the Irish Free State, 1922-1935
}

\author{
Dr ThOMAs MOHR
}

Lecturer in Law, School of Law, University College Dublin

\section{Introduction}

$\mathrm{T}$ The secession of the Irish Free State from the United Kingdom in 1922 left a considerable number of Irish Protestants on the southern side of the border. In 1926 there were just over 200,000 Protestants in the Irish Free State out of a total population of just under 3 million. ${ }^{1}$ This was a considerable reduction from the just over 300,000 Protestants out of a total population of just over 3 million who had been recorded in the 26 counties in the census of $1911 .^{2}$ It is difficult to attribute this considerable disparity in numbers to anything other than the traumatic nature of the birth of the Irish Free State. A reduction of one-third in just 15 years cannot be explained by considerations of high mortality, low fertility, religious conversions or even the withdrawal of British security forces in 1922. Kevin O’Higgins, Minister for Home Affairs, admitted to the Dáil in 1922 that:

$[\mathrm{C}]$ ertain people differing from the majority in religion, and perhaps also, and I am not sure of that, even in political outlook, were driven from their homes and from their positions in greater numbers than I was aware of until quite recently. ${ }^{3}$

Despite this dramatic drop in numbers, a significant number of southern Protestants remained in the new Irish Free State. Many southern Protestants were Unionists and continued to identify with that tradition after the creation of the new state.

The 'abandonment' of a large number of loyal British subjects in the southern and western parts of Ireland remained an emotive issue at Westminster and in the British media for many years. Yet, it was argued that the minority community had not been left without important safeguards of their religious and political rights. The necessity for these safeguards was recognised by the Irish provisional government itself. Kevin O'Higgins recognised the real fears that existed within the minority community and expressed some sympathy for its position at the break-up of the Union 'when the thing they looked to and

1 In this context, the term 'Protestants' includes Protestant Episcopalians, Presbyterians, Methodists and Baptists. The decline in the Protestant population of the 26 counties that would eventually form the Irish Free State is discussed in Robert E Kennedy, The Irish: Emigration, Marriage and Fertility (University of California Press 1973) 110-38.

2 Ibid.

3 Dáil Debates, vol 1, col 572 (21 September 1922). 
felt was a buttress and shelter for them is suddenly swept away and they find themselves in the awful position of being at the mercy of their fellow countrymen'. ${ }^{4}$

\section{Minority safeguards}

On 6 December 1921 British and Irish representatives signed the document popularly known as 'the Treaty' in Ireland. ${ }^{5}$ The months that followed saw the gradual crystallisation of the institutions of the new self-governing state in the 26 counties of the south and west of the island of Ireland. Some of the most important institutions were designed to ensure that southern Protestants would have a significant voice in the political affairs of the new state. The new Irish Parliament, or Oireachtas, included an upper house of parliament, or Seanad, which was to be elected from a single electoral area that spanned the entire Irish Free State. ${ }^{6}$ The lower house, or Dáil, was to be elected on a proportional representation voting system. Both measures were designed to ensure that the Protestant population, scattered throughout the territory of the new state, would be able to elect representatives to the Oireachtas. In addition, eleventh-hour amendments provided that three representatives from Trinity College Dublin and three from the National University of Ireland would sit in the Dáil. ${ }^{7}$ The guarantee of three representatives from Trinity College Dublin, then a bastion of the minority community, was often perceived to be a concession to Southern Protestants. ${ }^{8}$

Article 8 of the Constitution of the Irish Free State provided guarantees of freedom of conscience and free profession and practice of religion. This article also provided that no law would be made directly or indirectly to endow any religion. In addition, Article 8 sought to prevent religious discrimination in the sphere of education. ${ }^{9}$ In 1922 the Irish provisional government had proposed a much more succinct guarantee of freedom of religion. ${ }^{10}$ The British government was not satisfied with this and had insisted on the detailed provisions

4 Dáil Debates, vol 1, col 482 (20 September 1922).

5 Its official name was 'Articles of Agreement for a Treaty between Great Britain and Ireland'.

6 Article 32, Constitution of the Irish Free State.

7 Article 27, Constitution of the Irish Free State.

8 University representation was originally intended for the Seanad and not the Dáil. The original initiative to move university representation from the upper to the lower house was not based on arguments relating to safeguards for Southern Protestants: Dáil Debates, vol 1, cols 1106-33 (4 October 1922). However, this initiative was soon perceived in this light. This factor certainly influenced the success of the relevant amendment: Dáil Debates, vol 1, cols 1151-57 (4 October 1922); col 1725 (18 October 1922); and col 1916-17 (25 October 1922). University representation in the Dáil and the Irish Free State Seanad were abolished in 1936. However, it should be noted that a new Seanad was created by the constitution of 1937 with powers that differ from those enjoyed by its predecessor. This Seanad includes representation from Trinity College Dublin as provided under Article 18.4.1.

9 Article 8 provided: 'Freedom of conscience and the free profession and practice of religion are, subject to public order and morality, guaranteed to every citizen, and no law may be made either directly or indirectly to endow any religion, or prohibit or restrict the free exercise thereof or give any preference, or impose any disability on account of religious belief or religious status, or affect prejudicially the right of any child to attend a school receiving public money without attending the religious instruction at the school, or make any discrimination as respects State aid between schools under the management of different religious denominations, or divert from any religious denomination or any educational institution any of its property except for the purpose of roads, railways, lighting, water or drainage works or other works of public utility, and on payment of compensation.'

10 Article 9 of the draft constitution produced by the provisional government in May 1922 provided: 'Freedom of conscience and the free profession and practice of religion are inviolable rights of every citizen, and no law may be made either directly or indirectly to endow any religion, or to give any preference, or to impose any disability on account of belief.': UCD Archives, Kennedy Papers, P4/326, Document No 39. This article was broadly similar to Article 8 of Drafts A and B produced by the Constitution Committee: National Archives of Ireland (NAI), Department of the Taoiseach, S8953. 
that eventually appeared in Article 8 . These provisions had a long provenance and were based on s 3 of the Government of Ireland Act 1914 and s 5 (1) of the Government of Ireland Act 1920. Similar provisions had, in turn, been replicated in Article 16 of the 1921 Treaty. The sensitivity of religious matters resulted in a reluctance to depart from this established formula in 1922. In the 1930s de Valera also seems to have recognised the need to tread carefully in this area. This is evident from the fact that almost identical provisions to those that appeared in the 1922 constitution now appear in Article 44 of the current constitution of 1937 .

The first Seanad, which as a transitional measure had half of its members elected by the Dáil and the other half nominated by the President of the Executive Council, ${ }^{11}$ included many prominent Southern Protestants such as W B Yeats, Oliver St John Gogarty, Sir Horace Plunkett, the Earl of Dunraven, James Douglas, the Earl of Granard, Andrew Jameson, the Earl of Kerry, Alice Stopford Green, the Earl of Mayo, the Marquess of Headfort, the Earl of Wicklow and Douglas Hyde, who would go on to serve as President of Ireland between 1938 and 1945. The first chairman or Cathaoirleach of the Seanad was Lord Glenavy. ${ }^{12}$ This list, which is far from exhaustive, is notable for the large number of titled gentry and for its mixture of Protestants of Nationalist and Unionist sympathies. The installation of so many Southern Protestants in the Seanad cannot be entirely attributed to an enlightened policy by the Irish government. Southern Protestant negotiators secured a guarantee, during a series of Anglo-Irish negotiations in London in the summer of 1922, that a number of important professional bodies, in which Protestants were well represented, would have an input into nominations for the initial membership of the Seanad. ${ }^{13}$ Nevertheless, the composition of the Seanad between 1922 and 1936 does reflect a perceived need to reconcile an insecure minority community to the new state and its institutions.

Despite the above concessions, a team of Southern Protestant negotiators emerged dissatisfied from a series of Anglo-Irish talks held in London in June 1922. In particular, they were unhappy with the institution of the Seanad as an effective safeguard for the minority community. Lord Midleton, John Henry Bernard (Provost of Trinity College Dublin), Lord Donoughmore and Andrew Jameson believed that, despite the initial award of a generously disproportionate number of senators, Southern Protestants would only have minority representation in a house of parliament that would, in time, be popularly elected. The limited powers of the Seanad were also seen as inhibiting its ability to safeguard the minority community. The four Southern Protestants made their dissatisfaction clear in a letter that was published in the newspapers on 16 June 1922, the same day that the text of the draft Constitution of the Irish Free State was revealed to the public. ${ }^{14}$

11 Article 82, Constitution of the Irish Free State.

12 James Henry Mussen Campbell, first Baron Glenavy (1851-1931), was a barrister and Unionist MP. He served as Solicitor General for Ireland (1901-1905), Attorney General for Ireland (1905 and 1916), Lord Chief Justice of Ireland (1916-1918) and Lord Chancellor of Ireland (1918-1921). On his retirement from the office of Lord Chancellor he was created Baron Glenavy of Milltown, County Dublin. In 1923 he was appointed as chairman of the Judiciary Committee that advised the Irish government on the creation of a new judicial system. He held the office of Cathaoirleach of Seanad Éireann from 1922 to 1928.

13 These included the Chamber of Commerce, the Royal College of Physicians of Ireland, the Royal College of Surgeons in Ireland, the Benchers of the Honorable Society of King's Inns, Dublin, the Incorporated Law Society of Ireland and the councils of the County Boroughs of the Irish Free State. This was the basis of an agreement reached between Arthur Griffith and Lord Middleton, John Henry Bernard, Lord Donoughmore and Andrew Jameson: The National Archives-Public Records Office (TNA-PRO) CAB 43/3 SF(C) 37, draft constitution and CAB 43/3 SF(C) 42, Conference on Ireland, 15 June 1922.

14 Irish Times (16 June 1922). 


\section{The Privy Council appeal as a minority safeguard}

Many of the concessions detailed above are not unfamiliar to Irish constitutional historians. This article will focus on a much less known legal institution that was seen as safeguarding the rights of the minority community of the Irish Free State. This was the appeal from the Irish courts to the Judicial Committee of the Privy Council.

The jurisdiction of the Judicial Committee of the Privy Council has its roots in the medieval concept of the King as the fount of all justice throughout his Dominions. The right to hear and determine appeals in the territories controlled by the King of England was considered to be a crown prerogative. By the late seventeenth century, appeals to the King in Council were heard by ad hoc appeals committees. Lord Chancellor Henry Brougham brought increased order and professionalism to the appeals process when he ensured that a new 'Judicial Committee of the Privy Council' was placed on a statutory basis with the passage of the Judicial Committee Act $1833 .{ }^{15}$ By the early twentieth century the Judicial Committee of the Privy Council, better known by its shorter but not entirely accurate name of the 'Privy Council', was the final court of appeal for all the constituent parts of the British empire with the exception of the United Kingdom itself. ${ }^{16}$ When the Irish Free State came into existence as a self-governing Dominion of the empire, it too was obliged to accept this institution. British insistence on this point ensured that an unhappy Irish government finally acquiesced to the recognition of an appeal from the Irish Supreme Court to the Privy Council in Article 66 of the Irish constitution of 1922. ${ }^{17}$ Once this had been accepted, the British government attempted to allay the fears of some Southern Protestants by emphasising that this institution would ensure that a court sitting in London would act as the final arbiter of their rights. It was held out to the Protestant community of the Irish Free State as the ultimate safeguard in the event of discrimination by the dominant majority. This was not a novel argument. The Privy Council appeal was also seen as safeguarding the rights of other minority groups throughout the British empire, such as the French-speaking community in Canada and the Maoris of New Zealand. ${ }^{18}$

15 This was later amended by the Judicial Committee Act 1844. John A Costello argued that this amending legislation did not apply to the Irish Free State: UCD Archives, Costello Papers, P190/94, memorandum on Lynham v Butler, undated. Historical accounts of the origins and significance of the Privy Council appeal can be found in Peter Anthony Howell, The Judicial Committee of the Privy Council 1833-1876 (Cambridge University Press 1979) and Thomas Mohr, "A British Empire Court": A Brief Appraisal of the History of the Judicial Committee of the Privy Council' in Anthony McElligott et al (eds), Power in History: From Medieval Ireland to the Post Modern World - Historical Studies XXVII (Irish Academic Press 2011).

16 Appeals to the Judicial Committee of the Privy Council from within the United Kingdom have long been limited to a few obscure and archaic areas of jurisdiction. These include appeals from certain ecclesiastical courts and disputes under the House of Commons Disqualification Act 1975, which prohibits certain groups of people from sitting in the lower house of the British Parliament. The Privy Council is also empowered to hear appeals from the Court of Admiralty of the Cinque Ports. The last full sitting of this court occurred in 1914. In the 1990s the Privy Council was empowered to hear appeals relating to the devolution of powers to legislative assemblies in Scotland, Wales and Northern Ireland: Scotland Act 1998; Government of Wales Act 1998; and Northern Ireland Act 1998. This jurisdiction has since been transferred to the new Supreme Court of the United Kingdom, which was established in October 2009 following the enactment of the Constitutional Reform Act 2005. See Mohr (n 15).

17 Article 66 provided: 'The decision of the Supreme Court shall in all cases be final and conclusive, and shall not be reviewed or capable of being reviewed by any other Court, Tribunal or Authority whatsoever. Provided that nothing in this Constitution shall impair the right of any person to petition His Majesty for special leave to appeal from the Supreme Court to His Majesty in Council of the right of His Majesty to grant such leave.' See Thomas Mohr, 'Law without Loyalty: The Abolition of the Irish Appeal to the Privy Council' (2002) 37 Irish Jurist 187-226.

18 For example, see David Harkness, The Restless Dominion (New York University Press 1969) 93 and 114 and Megan Richardson, 'The Privy Council and New Zealand' 46 (1997) International \& Comparative Law Quarterly 908. 
Successive Irish governments were deeply hostile to the appeal to the Privy Council from the Irish courts in the 1920s and 1930s. It was seen as a serious limitation on Irish judicial sovereignty. ${ }^{19}$ In addition, the suggestion that the rights of Southern Protestants required protection by means of recourse to an external court was often perceived as an affront to the honour of the infant Irish Free State. ${ }^{20}$ Irish ministers asserted with total confidence that the great majority of Southern Protestants did not actually want this purported safeguard. Patrick McGilligan, Minister for External Affairs, stated that: 'The religious minority numbers one in nine of the entire population, of these, not an infinitesimal proportion desires the retention of the appeal. ${ }^{21} \mathrm{~W}$ T Cosgrave, first President of the Executive Council, wrote: 'As a Court there is no support for it here outside of a small section of the minority. 22 Those who did support the appeal were dismissed by McGilligan as a 'small clique', 'a handful of extremists' and even 'a small group . . . who wish to perpetuate religious strife'. ${ }^{23}$ Some of these contentions have received the support of legal historians writing in recent decades. For example, David Swinfen concludes that appeal from the courts of the Irish Free State only enjoyed the support of 'a tiny vociferous, proportion of former Unionists'. ${ }^{24}$

19 In 1922 Professor William Magennis of University College Dublin told the Dáil, sitting as a special Constituent Assembly: 'So long as there is an appeal of any sort . . Ireland is not independent.': Dáil Debates vol 1, col 1414 (10 October 1922). Barra Ó Briain's work on the Constitution of the Irish Free State concludes that the appeal 'constitutes the one real diminution of National Sovereignty contained in the Constitution': Barra Ó Briain, The Irish Constitution (Talbot Press 1929) 124. Leo Kohn's better known work on the 1922 constitution was no more restrained and declared that the appeal was 'the most obnoxious feature of the Constitution' and was repugnant to the general design of that legal instrument: Leo Kohn, The Constitution of the Irish Free State (Allen \& Unwin 1932) 355-56.

20 De Valera wrote as he put in place his preparations to abolish the Privy Council appeal in 1933: 'I am convinced that the minority as a whole are prepared to trust the good sense and the good will of their fellowcitizens who belong to the majority, and to work with them in securing the freedom and in building up the prosperity of their common country. That, if safeguard be needed, will, in the last resort, be the greatest safeguard of all.': NAI, Department of Foreign Affairs, 3/1.

21 UCD Archives, McGilligan Papers, P35/166, draft article 'Irish Free State and the Judicial Committee of the Privy Council', undated. Note: parts of the McGilligan Papers were reorganised in 2007. All documents in this article listed under P35/166 and P35/167 were originally listed under P35/196 before these files were reorganised.

22 Draft letter from W T Cosgrave to Lord Granard in Documents on Irish Foreign Policy, vol III, 1926-1932 (Royal Irish Academy 2002) 688.

23 Patrick McGilligan, 'Who Wants the Privy Council?' (May 1931) 1(9) The Star/An Reult - A National Review, 207. An article in The Times reported that McGilligan had referred to Southern Protestants as 'bigots': The Times (4 May 1931). McGilligan's article had actually stated: 'Except by a few frenzied bigots the view is held that it would be deplorable if Protestant Irishmen did not take the fullest part in every field of national activity on a footing of equality with their Catholic fellow-countrymen.' J W Dulanty, the Irish High Commissioner in London, protested in a letter to the editor of The Times that "the words "frenzied bigots" unmistakably referred to a small handful of Catholic extremists': UCD Archives, McGilligan Papers, P35/166, J W Dulanty to editor of The Times (7 May 1931). The assistant editor of The Times declined to apologise and pointed to the second heading of the article which referred to the 'Sinister and Disloyal Attempts of a Bigoted Handful to Work Up Feeling over its [the Privy Council's] Abolition by Saorstát': UCD Archives, McGilligan Papers, P35/166, R M Barrington to J W Dulanty, 7 May 1931. It is possible that McGilligan did not write this as no such heading appears in draft versions of this article: UCD Archives, McGilligan Papers, P35/166, draft article 'Who wants the Privy Council?'. See also the response of the Manchester Guardian (7 May 1931) to McGilligan's article which condemned his attitude towards the 'very moderate leaders of the Protestant community' in 'publicly denouncing them as bigots and extremists'.

24 David B Swinfen, Imperial Appeal (University of Manchester Press 1987) 124. 


\section{The Protestant community of the Irish Free State}

The Protestant population of the Irish Free State was often referred to as 'Southern Unionists' or 'Southern Loyalists'. It hardly needs to be stated that not all Protestants living in the Irish Free State would have described themselves in these terms. For example, Ernest Blythe, a Presbyterian born in Country Antrim, was an ardent Nationalist who held several ministerial portfolios in the 1920s and 1930s. ${ }^{25}$ The term 'Southern Unionist' would certainly not have been an accurate description of the political views of Mabel FitzGerald (née McConnell) despite her Presbyterian background. Her son Garrett, who would hold the office of Taoiseach for much of the 1980s, later wrote of how his mother in a moment of revolutionary fervour, told her former employer, George Bernard Shaw, that she would bring her eldest son up to hate England'. ${ }^{26}$ Her opposition to the 1921 Treaty contrasted with that of her husband Desmond FitzGerald, a member of the pro-Treaty government. It should also be noted that many Southern Unionists were not actually Protestants. ${ }^{27}$ Despite these complications, the Protestant inhabitants of the Irish Free State were often referred to as 'Southern Unionists', 'former Unionists' or often 'ex-Unionists'. ${ }^{28}$ The latter terms must have been offensive to many people whose political preferences had not necessarily been altered by the creation of the Irish Free State. One might imagine the reaction of the minority community of Northern Ireland to being described as 'exNationalists'. The term 'Southern Protestants' is not without its own difficulties based on considerations of geography and movements of people. Nevertheless, this article will use the term 'Southern Protestants' on the basis that it is preferable to all alternatives as a useful shorthand description of the Protestants living in or native to the 26 counties of the island of Ireland that would eventually form the territory of the Irish Free State.

\section{The Irish appeal to the Privy Council}

The origins of the Irish appeal lie in Articles 1 and 2 of the Treaty or Articles of Agreement signed in London in 1921. These provisions ensured that the Irish Free State came into existence as a Dominion of the British empire. ${ }^{29}$ Article 2 ensured that the Irish Free State was to hold the same constitutional status within the empire in certain key areas as was enjoyed by the Dominion of Canada. The British government led by David Lloyd George considered the institution of the Privy Council appeal to be essential in ensuring that the new Irish Free State was perceived as a British Dominion. The decisions of the courts of all the existing Dominions were, after all, subject to appeal to the Judicial Committee of the

25 (1889-1975) Minister for Trade and Commerce, First and Second Dáil 1919-1922; Minister for Local Government 1922-1923; Minister for Finance 1923-1932; and Vice-President of the Executive Council 1927-1932.

26 Garret FitzGerald, Ireland in the World (Liberties Press 2005) 189.

27 A detailed account of the Catholic Unionist tradition is provided in John Biggs-Davison and George Chowdharay-Best, The Cross of Saint Patrick: The Catholic Unionist Tradition in Ireland (Kensal Press 1984).

28 Eg TNA-PRO CAB 32/56 E (IR26) 4th Meeting, 2 November 1926, UCD Archives, McGilligan Papers, P35B/108 and NAI, Department of the Taoiseach, S4285B, transcript of radio broadcast of 9 November 1930. The term was sometimes used by Southern Protestant sources, eg, Irish Times (13 February 1932). It is still occasionally used today e.g. Liam Weeks, 'We Don't Like (to) Party. A Typology of Independents in Irish Political Life, 1922-2007’ (2009) 24(1) Irish Political Studies 1, 14.

29 The use of a capital ' $D$ ' when referring to the 'British Dominions' was required by the British government in order to avoid confusion with the wider term 'His Majesty's dominions' which referred to the British empire as a whole. See TNA-PRO HO 45/20030. This article will follow this convention. 
Privy Council. ${ }^{30}$ The British government also saw it as a means of safeguarding the rights of the Southern Protestant community in addition to providing a mechanism for maintaining the integrity of the settlement imposed by the 1921 Treaty. ${ }^{31}$ They insisted that, although the appeal to the Privy Council was not explicitly mentioned in the text of the Treaty, acceptance of the appeal was implicit in the overall acceptance of Dominion status. ${ }^{32}$ The Irish were far from happy with this position and made a determined effort in bilateral negotiations to exclude the appeal from the text of the constitution. This position had to be abandoned in the face of serious pressure from the British government. ${ }^{33}$

Despite this unfortunate beginning, the Privy Council appeal hardly disturbed the waters in the first few years of the existence of the Irish Free State. The Privy Council heard three Irish petitions for leave to appeal in 1923. ${ }^{34}$ The Irish government was relieved and reassured when all three were refused leave to appeal. ${ }^{35}$ This period of relative calm was obliterated in 1926 when the Privy Council granted leave to appeal in the case of Lynham v Butler. ${ }^{36}$ The case concerned the interpretation of certain provisions of the Land Act 1923. This was seen as matter of purely domestic significance and, as far as the Irish were concerned, this was not a matter that should have been the subject of an appeal to the Privy Council. The grant of leave to appeal revived earlier fears that the Privy Council appeal might be used by the British to meddle in the internal affairs of the Irish Free State. ${ }^{37} \mathrm{~A}$ new statute known as the Land Act 1926 was rushed through the Oireachtas that confirmed the interpretation of the Land Act 1923 given by the Irish Supreme Court during its consideration of the issues involved in Lynham $v$ Butler. ${ }^{38}$ This extraordinary measure effectively blocked any further consideration of this case by the Privy Council. Protestant members of the Seanad recognised the danger of the precedent represented by the Land Act 1926. Lord Glenavy, Cathaoirleach of the Seanad and chairman of the committee that had assisted in the creation of the new Irish judicial system, was deeply opposed to it and tried to convince many of the independent members of the Seanad to oppose the measure.

30 The appeal was based on crown prerogative and was regulated by imperial statutes such as the Judicial Committee Acts 1833 and 1844. See Peter Anthony Howell, The Judicial Committee of the Privy Council 1833-1876 (Cambridge University Press 1979) 3-71. The sources of Privy Council appeals between the years 1911 and 1917 have been estimated as follows: India 514; Canada 180; Australia 45; New Zealand 18; Newfoundland 6; South Africa 3: Irish Independent (31 December 1929).

31 Eg, see TNA-PRO CAB 43/1 SFB 21, Meeting between Representatives of the Southern Unionists and the British Representatives on the Conference on Ireland, 7 December 1921 and TNA-PRO CO 739/7/47027, Curtis to Churchill, 20 September 1922.

32 TNA-PRO CAB 43/7, 22/N/162, draft Irish constitution, 27 May 1922.

33 See Mohr (n 17).

34 These three petitions were Alexander E Hull and Co v Mary A E M'Kenna, The Freeman's Journal' Ltd v Erik Fernstrom and The Freeman's Journal' Ltd v Follum Traesliberi: all are reported at [1926] IR 402.

35 Irish observers at the proceedings, which included Hugh Kennedy and John A Costello, must have taken comfort from Lord Haldane's admission that 'it is obviously proper that the Dominions should more and more dispose of their own cases' and therefore the Judicial Committee did not interfere 'unless the case is one involving some great principle or is of some very wide public interest': [1926] IR 402, 404. Haldane concluded that the Irish Free State 'must in a large measure dispose of her own justice': [1926] IR 402, 407-08. Lord Buckmaster added that 'as far as possible, finality and supremacy are to be given to the Irish Courts' [1926] IR 402, 409. Hugh Kennedy, then Attorney General of the Irish Free State, wrote 'if they had been so dishonestly minded, the British side could have eaten into our rights very substantially': UCD Archives, Kennedy Papers, P4/516, Hugh Kennedy to W T Cosgrave, 30 July 1923.

36 [1925] 2 IR 82 (High Court) [1925] 2 IR 82 (Supreme Court).

37 Eg, UCD Archives (n 35).

38 A B Keith claimed that he had anticipated the use of such measures as the Land Act 1926 in advice given to Darrell Figgis during the drafting of the Irish constitution. Arthur Berriedale Keith, 'Notes on Imperial Constitutional Law' (1926) 8 Journal of Comparative Legislation \& International Law 286-87. 
His attempt to organise Protestant opposition to the measure was thwarted by Senator James Douglas, an opponent of the appeal, who argued strenuously against Glenavy in a meeting of Independent senators lasting over three hours. ${ }^{39}$ Although Southern Protestants did protest against the Land Act 1926 in the Oireachtas, they lacked the confidence to actually vote against it. ${ }^{40}$

Irish perceptions of the Privy Council appeal sank even further when the Irish government disputed two judgments concerning the compensation payable to civil servants who had been transferred from Great Britain to Ireland before 1922. ${ }^{41}$ The Irish insisted that the Privy Council had made fundamental errors in calculating the level of compensation payable to these persons. ${ }^{42}$ This time the Irish protest took the form of refusing to pay the awards fixed by the Privy Council. ${ }^{43}$ In short, the Irish executive refused to enforce the decisions of a court that was recognised by the provisions of the Irish constitution.

The next Irish appeal heard by the Privy Council was Performing Right Society $v$ Bray Urban District Council. ${ }^{44}$ This case concerned whether the Copyright Act 1911, a British imperial statute, applied to the Irish Free State. The Supreme Court held that it did not while the Privy Council held that it did. ${ }^{45}$ The decision of the Privy Council was more desirable from a practical perspective since it prevented the creation of a significant gap in the protection of copyright in the Irish Free State. Unfortunately, the deterioration of relations caused by previous appeals ensured that the Irish government refused to accept this judgment. ${ }^{46}$ Instead, the Oireachtas enacted special legislation, the Copyright (Preservation) Act 1929 that attempted to fill the lacunae in Irish copyright law created by the decision of the Irish Supreme Court. ${ }^{47}$

By the end of the 1920s the Irish government made no secret of its desire to abolish the appeal and spared no effort to achieve this goal. This objective was pursued at successive Imperial Conferences in the 1920s and 1930s. The Privy Council heard one more Irish case before the abolition of the appeal was placed beyond dispute. This was Moore $v$ Attorney General, a case that will be examined at a later stage in this article. ${ }^{48}$

It is readily apparent from this short but ignoble history that the foundations of the hostility of the Irish government towards the appeal centred on fears of diminution of sovereignty. Yet, the assertion that the appeal acted as a safeguard for Southern Protestants was also a significant cause of friction. Claims that such safeguards were necessary were seen as attempts to stir up dormant sectarian feelings. ${ }^{49}$ The antipathy of the Irish government towards the assertion that the Privy Council appeal acted as a minority safeguard was heightened by the perception that this safeguard had been introduced by means of subterfuge.

39 John Anthony Gaughan, Memoirs of Senator James G Douglas (1887-1954) Concerned Citizen (UCD Press 1998) 123-24.

40 Seanad Debates, vol 6, cols 395-445 (24 February 1926).

41 Wigg and Cochrane v The Attorney General of the Irish Free State [1927] IR 285; In the Matter of the Reference as to the Tribunal under Article 12 of the Schedule appended to the Irish Free State Agreement Act 1922 (Cmd 2214).

42 Robert Francis Vere Heuston, Lives of the Lord Chancellors 1885-1940 (Clarendon Press 1964) 441.

43 Irish Times (15 November 1928) and HL Deb 25 April 1928, vol 70, cols 819-20.

44 [1928] IR 512.

45 [1928] IR 512 (Supreme Court) and [1930] IR 509 (Privy Council).

46 See Mohr (n 17).

47 Copyright (Preservation) Act 1929.

48 [1935] IR 472 and [1935] AC 484.

49 For example, McGilligan (n 23) and UCD Archives, McGilligan Papers, P35/166, draft article 'Who wants the Privy Council?'. 


\section{The Irish appeal to the Privy Council as a minority safeguard}

In 1930 the Irish government ordered an extensive search of its files on the negotiations that led to the signing of the 1921 Treaty in order to discover any discussions on the appeal to the Privy Council as a minority safeguard. ${ }^{50}$ The failure to find any discussions on this issue buttressed a perception that this purported safeguard had been invented in the years that followed 1921 as a device for obstructing the desire of the Irish governments to abolish the appeal. 51

If the Irish government had examined pre-1921 material they might have found evidence that contradicted their assertion that arguments concerning the utility of the Privy Council appeal as a minority safeguard had only been raised after the signature of the Treaty. The Bills and Acts relating to Irish Home Rule made it clear that the Privy Council had been intended to act as the arbiter of these settlements in the event of dispute. ${ }^{52}$ In this context, the Privy Council appeal had long been promoted as a safeguard for Irish Protestants living under a Home Rule Parliament. ${ }^{53}$ In addition, it was well known that the Privy Council appeal was perceived to be a minority safeguard in other parts of the empire, most notably by the French-speakers of Canada.

The potential offered by the Privy Council appeal to safeguard the rights of Southern Protestants gained greater importance as the possibility of total secession of parts of Ireland from the United Kingdom became a real possibility. Southern Protestant representatives discussed this safeguard with the British government before and immediately after the signature of the 1921 Treaty. The Church of Ireland Archbishop of Dublin $^{54}$ raised the Privy Council appeal in correspondence with Lloyd George in October 1921. 55 The day after the Treaty was signed Lloyd George met a delegation of Southern Protestants, consisting of Lord Midleton, Lord Desart, John Henry Bernard and Andrew Jameson. The British Prime Minister used the Privy Council appeal to counter Midleton's complaint that the terms of the Treaty offered nothing to Southern Protestants. ${ }^{56}$ Although

50 NAI, Department of the Taoiseach, S4285A, Michael McDunphy to W T Cosgrave, 8 November 1930, and Michael McDunphy to Diarmuid O’Hegarty, 8 November 1930.

51 This formed the basis for a line of argument that was used in Anglo-Irish negotiations and at the Imperial Conferences of the 1920s and 1930s. Eg, see TNA-PRO CAB 32/79 PM (30)18 Appendix, meeting of prime ministers and heads of delegations, 5 November 1930, and NAI Department of the Taoiseach, S4285A, memorandum for the Imperial Conference of 1930, undated.

52 S 25 of the Irish Government Bill 1886, better known as the first Home Rule Bill, would have empowered the Judicial Committee to decide whether legislation passed by the proposed Irish Parliament was intra vires; in other matters, the appeal from the Irish courts to the House of Lords would have remained intact: ss 25 and 36 of the Irish Government Bill 1886: <http://multitext.ucc.ie/d/Home_Rule_Bill_1886> accessed 20 July 2011. The Irish Government Bill 1893 and the Government of Ireland Act 1914 would have completely replaced the jurisdiction of the House of Lords with that of the Privy Council. They also contained provisions that would have allowed for the 'speedy determination' by the Judicial Committee of such constitutional questions as the validity of laws passed by the Irish legislature. Ss 28 and 29 of the Government of Ireland Act 1914 were virtually identical to ss 22 and 23 of the Irish Government Bill 1893. S 30 of the 1914 Act contained additional provisions that were not found in the 1893 Bill. For the full text of the 1893 Bill see 'The Home Rule Bill, 1893' (1893) 67 Pall Mall Gazette Extra. The Government of Ireland Act 1920 retained the appeal to the House of Lords but gave special jurisdiction to the Privy Council to decide certain constitutional questions: ss 49 to 53 of the Government of Ireland Act 1920.

53 Eg, see Sir John MacDonell, 'Constitutional Limitations upon the Powers of the Irish Legislature and the Protection of Minorities' in John Hartman Morgan (ed), The New Irish Constitution (Hodder \& Stoughton 1912) 110.

54 John Allen FitzGerald Gregg, popularly known as 'John Dublin' (1873-1961), Archbishop of Dublin and Glendalough (1920-1939), Archbishop of Armagh (1939-1959).

55 TNA-PRO LCO 2/910, Archbishop of Dublin to Prime Minister, 27 September 1930.

56 TNA-PRO CAB 43/1 SFB 21, Meeting between Representatives of the Southern Unionists and the British Representatives on the Conference on Ireland, 7 December 1921. 
this safeguard was not mentioned in the text of the Treaty, Lloyd George revealed the intention of the British government to use the constitutional link with Canada in Article 2 of the Treaty to secure an appeal to the Privy Council from the Irish courts. ${ }^{57}$ The existence of an appeal to the Privy Council from the Canadian courts ensured that the same position would have to apply to the Irish Free State.

The complaints raised by Irish governments in the 1920s and 1930s to the effect that the British delegation did not raise this potential safeguard with their Irish counterparts during the Treaty negotiations might well have been justified. It was certainly not in the interests of the British government to raise this difficult issue at this juncture. ${ }^{58}$ The British did raise the Privy Council appeal in public after the Treaty was safely signed. The appeal was discussed in some detail during the negotiations on the provisions of the draft Irish constitution that took place in the summer of 1922. Yet, the British still refrained from emphasising the potential of the appeal to offer minority safeguards to the Protestant population of the embryonic Irish Free State. It is unlikely that such an argument would have impressed the Irish representatives and, in any case, the British were anxious to play down the significance of the Privy Council appeal at this point. The negotiating stance adopted by the British government on the Privy Council appeal focused on the constitutional link with Canada established by Article 2 of the 1921 Treaty. The Irish were under the impression that appeals from the Irish courts would be rare and exceptional events. ${ }^{59}$ Emphasis on the use of the appeal as the guarantor of the rights of Southern Protestants would have undermined this expectation. It would also have heightened Irish fears as to the potential offered by appeal to meddle in the internal affairs of the Irish Free State. The Irish representatives at these negotiations paid little heed to Home Rule antecedents or to perceptions of the appeal by minorities in other parts of the empire. The absence of detailed discussions on the use of the Privy Council appeal as a minority safeguard was clearly advantageous to the British negotiating position in 1921 and 1922 . Yet, it had unfortunate consequences in the longer term. When the minority safeguard argument was raised in the years that followed, the Irish government perceived it as an issue that had fallen from a clear blue sky.

Rejection of the minority safeguard argument became more vociferous as the attitude of the Irish government hardened towards the Privy Council in the aftermath of the dispute surrounding Lynham v Butler and the appeals concerning transferred civil servants. On 9 November 1930 Patrick McGilligan made a radio broadcast to the United States of America that consisted, for the most part, of an emotive diatribe against the Privy Council. The appeal was presented as 'the last element of British control in Ireland'. McGilligan was particularly eager to refute the argument that the appeal was of any utility as a minority safeguard. According to McGilligan, 'Irish Catholics have never been guilty of religious intolerance.' This sweeping statement did not prevent McGilligan from describing Southern Protestants as 'people whose ancestors had been responsible for a regime of religious bigotry and intolerance in Ireland'. He also associated them with 'the remnants of a class which had lived on the toil of Irish peasants working on lands which centuries ago had been torn from the Irish people'. 60

57 Ibid.

58 TNA-PRO CO 532/257, Lionel Curtis to Sir James Masterson Smith, 8 October 1923 and 1 November 1923.

$59 \mathrm{Eg}$, Kevin O'Higgins went so far as to assert that leave to appeal would be limited to cases that involved 'international issues of the first importance': Dáil Debates, vol 1, col 1404 (10 October 1922). See also TNAPRO LCO 2/910, Dominions Secretary to Lord Chancellor, 17 February 1926.

60 NAI, Department of the Taoiseach, S4285B, transcript of radio broadcast of 9 November 1930. 
Although the Irish government was deeply hostile to perceptions of the Judicial Committee of the Privy Council as the champion of the minority community in the Irish Free State, it had to recognise that this contention created a serious obstacle to the abolition of the appeal. Complaints made by Irish ministers that this issue had not been examined in detail during the Anglo-Irish negotiations of 1921 and 1922 were not sufficient to remove this issue from the political agenda in the years that followed. These considerations ensured that the Irish government adopted four additional approaches in its efforts to undermine the image of the Privy Council as the ultimate safeguard for the rights of Southern Protestants.

\section{Challenging the appeal}

\section{INEFFICACY}

The first approach used by the Irish government was to stress the inefficacy of the appeal to serve as a minority safeguard. It could not be denied that the decisions of this court had been thwarted on at least four separate occasions in the 1920s. The appeal in Lynham v Butler and the decision in Performing Right Society v Bray Urban District Council were blocked by special legislation. ${ }^{61}$ The decisions in the two cases concerning the transferred civil servants had simply been ignored until the British government brokered a successful compromise. ${ }^{62}$ Patrick McGilligan told delegates to the Imperial Conference of 1930 that the Oireachtas could ensure 'that any interpretation contrary to the decision of the Irish courts could be nullified'. 63 The success of the Irish government in blocking or ignoring appeals allowed one Irish commentator, Hector Hughes, in a monograph on Judicial Autonomy in the Dominions, to insist that the Privy Council appeal was no more than a 'paper safeguard' for minorities. ${ }^{64}$ Hughes insisted that an oppressive majority community could never be forced to accept the decisions of the Privy Council. He concluded that the Privy Council had 'no way - short of physical force, which even is not available to it - of enforcing its decisions'. ${ }^{65}$ The difficulty with this argument is that it could be raised in relation to any court of law. It was an argument that rested on assertions of power on the part of the majority community rather than on any overriding moral consideration. Those who argued that the decisions of the Privy Council had been made ineffective in the past could not ignore the inconsistency with respect for rule of law that characterised many of these actions. ${ }^{66}$ If anything, these

61 The Land Act 1926 prevented the appeal in Lynham v Butler [1925] 2 IR 82 (High Court) [1925] 2 IR 82 (Supreme Court) from going ahead while the Copyright (Preservation) Act 1929 ensured that the Privy Council could do no more than award costs in Performing Right Society v Bray Urban District Council [1930] IR 509.

62 The difference between the amount of compensation for the transferred civil servants calculated on the basis of the Privy Council decisions and the amount calculated by the Irish Supreme Court was recouped by the British government. This solution was cemented by the enactment of parallel legislation, Civil Service (Transferred Officers) Compensation Act 1929 (Dublin) and the Irish Free State (Confirmation of Agreement) Act 1929 (Westminster).

63 TNA-PRO CAB 32/88 E (IR) (30) 8th meeting, 21 October 21. See also, NAI, Department of the Taoiseach, S4285A, memorandum for the Imperial Conference of 1930, undated.

64 Hector Hughes, National Sovereignty and Judicial Autonomy in the British Commonwealth of Nations (P S King 1931) 109.

65 Ibid 108.

66 It should be recalled that the attempts to obstruct the decisions of the Privy Council were not the only extraordinary legal measures being taken at this time. Other examples included the Public Safety Act 1927, which explicitly overrode the provisions of the constitution, the Constitution (Amendment No 16) Act 1929, which could be seen as fatally undermining the intention that constitutional amendments should be approved by means of referenda after the expiry of an eight-year transitional period and the Constitution (Amendment No 17) Act 1931, which created a new system of military courts with sweeping powers. In this context, the use of retrospective legislation to thwart the jurisdiction of a court or, in other cases, the simple refusal to enforce its directions could be seen as evidence of a serious deterioration in respect for the integrity of law in the Irish Free State. 
considerations seemed to bolster, rather than undermine, arguments that minority safeguards were indeed necessary. Nevertheless, as will become apparent, this 'lack of efficacy' argument did convince a number of prominent Southern Protestants to withdraw their support for the continuance of the Irish appeal to the Privy Council.

\section{LACK OF NECESSITY}

More constructive attempts at undermining the image of the Privy Council as the champion of Southern Protestants focused on the assertion that there was no real necessity for a minority safeguard of this nature. Kevin O'Higgins told the Imperial Conference of 1926 that the 'ex-Unionists' were among the 'best citizens' the Irish Free State had. ${ }^{67}$ A memorandum written for the Imperial Conference of 1930 stressed that Southern Protestants:

$[\mathrm{H}]$ ave never suffered discrimination or injustice. They have been accepted in the fullest sense as fellow-citizens, they have with the exception of a negligible number of irreconcilables accepted the position themselves. ${ }^{68}$

It was also emphasised that Southern Protestants were well represented in the ranks of the judiciary of the Irish Free State. ${ }^{69}$

The Protestant community of the Irish Free State could not compare its position to the level of discrimination endured by the Catholic community in Northern Ireland in the interwar years and beyond. Yet, this did not mean that sectarian tensions were absent from the 26 counties. Protestant members of the Oireachtas had to endure jibes from Fianna Fáil TDs and the Irish Press, which identified them with freemasonry and British imperialism and as the British garrison in Ireland. Sectarian attacks had occurred during the Anglo-Irish conflict of 1919 to $1921 .^{70}$ During the lifetime of the Irish Free State it became clear that Protestants often had different ethical positions on matters such as censorship, divorce and contraception to those of their Catholic neighbours. Protests based on the position that the new state should not impose Catholic principles on the entirety of the population of the Irish Free State seldom evoked a sympathetic response. ${ }^{71}$ The Ne Temere decree, which required non-Catholics in a mixed marriage to agree to raise and educate their children as Catholics, remained a source of contention for much of the twentieth century. ${ }^{72}$ The burning of Protestant churches in the 1930s as reprisals for attacks against Catholics in

67 TNA-PRO CAB 32/56 E (IR26) 4th Meeting, 2 November 1926.

68 NAI, Department of the Taoiseach, S4285A, memorandum for the Imperial Conference of 1930, undated.

69 It has been suggested that the Irish state has maintained a conscious policy of ensuring that religious minorities are represented in the ranks of the judiciary. Paul C Bartholomew, The Irish Judiciary (University of Notre Dame Press 1971) 39-40. A draft speech on the Privy Council written by Eamon de Valera in 1933 stressed that one out of three members of the Supreme Court and four out of six members of the High Court were Protestants: NAI, Department of Foreign Affairs, file 3/1, draft speech on 'Abolition of Appeals to the Privy Council', undated 1933. At the time of writing of this article the first Protestant, Susan Denham, has just been appointed as Chief Justice of the Irish Supreme Court.

70 See Peter Hart, 'The Protestant Experience of Revolution in Southern Ireland' in Richard English and Graham Walker (eds), Unionism in Modern Ireland: New Perspectives on Politics and Culture (Macmillan 1996) 81-98.

71 See John Henry Whyte, Church and State in Modern Ireland, 1923-1979 (Gill \& Macmillan 1984) 57-60

72 This decree also resulted in litigation, most notably in the case of In re Tilson, Infants [1951] IR 1. See also Gerard Hogan, 'A Fresh Look at Tilson's Case' (1998) 32 Irish Jurist 311. It is interesting to speculate what might have happened if this case had been heard two decades earlier and appealed to the Privy Council. It has been suggested that the Irish courts may have been guilty of bias in the past with respect to child custody disputes between Catholic and non-Catholic spouses: Bartholomew (n 69) 17-18. 
Northern Ireland and the Fethard-on-Sea boycott in the late 1950s illustrate that the creation of the self-governing Irish State had not eliminated sectarian tensions. ${ }^{73}$

One of the most notorious incidents of this nature during the lifetime of the Irish Free State itself was the rancorous dispute fuelled by the appointment of Letitia DunbarHarrison, a Protestant graduate of Trinity College Dublin, as a librarian in County Mayo. The Local Appointments Commission had recommended Harrison for the post in 1930. Nevertheless, the Mayo Library Committee refused to endorse the appointment. This body objected to the appointment on two grounds. First, it was noted that she had no qualifications in the Irish language. This objection ignored Harrison's entitlement to a period of three years in which to obtain such a qualification. The second objection was that a Protestant was not a suitable person to supervise the reading of a population that was overwhelmingly Catholic. Richard Mulcahy, Minister for Local Government, responded by suspending Mayo County Council when it threw its support behind the library committee. Harrison was duly appointed to the position, although pragmatic considerations ensured her rapid promotion and transfer to a more congenial post in the library of the Department of Defence in Dublin. The robust response of the Irish government transformed a shortterm disaster into a major publicity coup for the Irish Free State. The dispute was widely reported in the international press, which ensured that the Irish government received widespread praise for its strong stance against religious intolerance. ${ }^{74}$

The Dunbar-Harrison incident is significant because the Irish government made extensive use of it to support its case that the Protestant minority did not require external intervention in order to uphold its rights. ${ }^{75}$ Yet, this dispute was not an untrammelled propaganda victory for the Irish Free State as a tolerant society. Eamon de Valera tarnished this image by his robust support for Mayo County Council. He told the Dáil:

I say that if I had a vote on a local body, and there were two qualified people who

had to deal with a Catholic community, and if one was a Catholic and another a

Protestant, I would unhesitatingly vote for the Catholic. ${ }^{76}$

One of the most important methods of attacking the need for the appeal as a minority safeguard was to argue that none of the Irish cases heard by the Privy Council had ever involved any question of religion. ${ }^{77}$ Some Southern Protestants did argue that official efforts to prevent the availability of divorce constituted religious discrimination and violated Article 8 of the constitution, but these complaints never crystallised into a legal challenge. ${ }^{78}$ Nevertheless, those who emphasised the lack of religious content in any of the Irish appeals to the Privy Council failed to consider that perceived attacks on the rights of the minority community need not have been directly concerned with matters of religion.

73 Kurt Bowen, Protestants in a Catholic State: Ireland's Privileged Minority (McGill-Queen's University Press 1983) 64, and T Fanning, The Fethard-on-Sea Boycott (Collins 2010). See also Heather K Crawford, Outside the Glow: Protestants and Irishness in Independent Ireland (University College Dublin Press 2010) and Marianne Elliott, When God Took Sides: Religion and Identity in Ireland: Unfinished History (Oxford University Press 2009).

74 Eg, (1931) 21 Round Table 404.

75 Eg, see UCD Archives, McGilligan Papers, P35B/115, Walshe to McGilligan, undated; TNA-PRO LCO 2/910, note by Sir H Batterbee and Mr Machtig, 27 February 1931 and (1931) 21 Round Table 404.

76 Dáil Debates, vol 39, col 517 (17 June 1931). An interesting analysis of the Dunbar-Harrison incident can be found in Whyte (n 71) 44-47. This controversy had a predecessor in the form of a letter from a parish priest, which was read out in the Dáil by a Fianna Fáil TD, complaining of the appointment of a Protestant doctor to serve a Catholic community in County Meath. De Valera followed this by giving notice that he would not be afraid of dealing with religious considerations when making appointments: Dáil Debates, vol 24, cols 346-49 and 368 (8 June 1928).

77 Eg, Hughes (n 64) 107-09.

78 Irish Times (23 February 1925) and Dáil Debates, vol 10, cols 158-82 (11 February 1925). 
The transferred civil servants involved in Wigg and Cochrane v Attorney General and the special reference that followed were, accurately or otherwise, perceived to be Protestants and Unionists by their supporters. ${ }^{79}$ The appellants in Moore v Attorney General were Protestants from Donegal and Derry. The case involved a challenge to their exclusive fishing rights on the tidal estuary of the river Erne by a number of fishermen. The description of the owners of these property rights as 'foreigners' by those who instigated the legal action reflects an unpleasant sectarian aspect to this dispute. ${ }^{80}$

It is important not to place disproportionate emphasis on isolated incidents such as the Dunbar-Harrison dispute or the events surrounding Moore $v$ Attorney General when examining the position of the Southern Protestant community as a whole during the lifetime of the Irish Free State. The short span of time since the conclusion of the bloody conflict that had preceded the creation of the Irish Free State is far more important in explaining the sense of vulnerability that persisted among many Southern Protestants. The Church of Ireland Archbishops of Armagh and Dublin, Charles Frederick D'Arcy and John Allen FitzGerald Gregg, emphasised that 'memories in Ireland are long' in a letter to The Times supporting the retention of the Privy Council appeal. ${ }^{81} \mathrm{~A}$ British memorandum written in 1926, in response to calls by the Irish government to abolish the Privy Council appeal, made clear that:

the bitterness of the past cannot be wiped out in three years, and there is still a substantial minority in the Free State who would regard the abolition of the right to petition for special leave to appeal to His Majesty in Council as a betrayal at the hands of the British Government. ${ }^{82}$

\section{ABSENCE OF PROTESTANT SUPPORT}

A third approach in challenging the claim that the Privy Council provided a minority safeguard focused on the Southern Protestant community itself. Irish officials were anxious to dismiss claims that Southern Protestants valued the Privy Council appeal as a safeguard of their rights and freedoms. Kevin O'Higgins used this approach to deny the reality of this minority safeguard at the Imperial Conference of 1926 and successive Irish governments repeated it throughout the $1920 \mathrm{~s}$ and $1930 \mathrm{~s} .{ }^{83}$ O'Higgins went so far as to claim that if a plebiscite were taken on the Privy Council appeal the only persons who would be found to support it in the Irish Free State would be members of the Irish Bar. Members of the legal profession were seen as having an obvious interest in maintaining what the Irish government characterised as a 'rich man's appeal'. ${ }^{84}$ Patrick McGilligan believed that only a small clique of Southern Protestants supported the appeal and equated this position to a desire to retain class privileges. ${ }^{85}$

79 Eg HL Deb 1 December 1931, vol 83, cols 232-33.

80 Donegal Democrat (12 August 1933).

81 The Times (7 November 1930).

82 TNA-PRO LCO 2/3465, Imperial Conference 1926, Appeals to the King in Council, 1 November 1926.

83 TNA-PRO CAB 32/56 E (IR26) 4th Meeting, 2 November 1926.

84 TNA-PRO CAB 32/56 E (IR26) 4th Meeting, 2 November 1926, and TNA-PRO CAB 43/3 SFC 40 Griffith to Lloyd George, 2 June 1922.

85 McGilligan (n 23) and UCD Archives (n 23). 
The Irish government was particularly keen to point to prominent Southern Protestants who had little time for the Privy Council appeal. ${ }^{86}$ Ernest Blythe was among the most obdurate opponents of the Privy Council appeal within the Irish government. ${ }^{87}$ In 1930 Senator James Douglas, a Quaker who had sat on the committee that created the early drafts of the 1922 constitution, wrote a letter to the press in order to refute claims made by other Southern Protestants as to the value of the appeal as a minority safeguard. ${ }^{8}$ Douglas considered that it was necessary for Southern Protestants to reject the appeal in order to prove their loyalty to the new state:

We, non-Catholics, in the Saorstát [Free State] cannot serve two masters, for else we will hold to one and despise the other. Loyal acceptance of the new order of things means trusting the majority to safeguard the rights of the minority. If the majority cannot be trusted, no constitutional provision however carefully worded - no political interference by an outside authority - no appeals to an outside Court will be of any avail whatever. ${ }^{89}$

Irish governments in the 1920s and 1930s were convinced that the minority safeguard argument was a convenient ruse employed by persons outside the 26 counties, who were hostile to the self-governing Irish state, to ensure the retention of the Privy Council appeal. John A Costello told the Imperial Conference of 1930 that, as far as he was aware:

No one in Ireland had ever put forward the argument that the 'Loyalists' [of the Irish Free State] should continue to receive the protection afforded by the appeal to the Judicial Committee: that was an argument only put forward in England. ${ }^{90}$

\section{A TOOL OF EXTERNAL INTERFERENCE}

The final means by which Irish governments attacked the assertion that the Privy Council appeal acted as a minority safeguard was to question its objectivity as a court of law. As far as Irish governments were concerned, a court that was subject to external influence was illequipped to act as the final arbiter concerning the relationship between the Irish state and religious minorities. Nationalist suspicions as to the objectivity of the Judicial Committee of the Privy Council were ostensibly based on the absence of clear separation of powers in key British institutions. The Lord Chancellor heard Privy Council appeals but also sat in the House of Lords and had a seat in the British Cabinet. ${ }^{91}$ Irish commentators, including members of the Irish government itself, openly questioned the independence of the Judicial Committee of the Privy Council vis-à-vis the British government. John A Costello wrote that the Judicial Committee had a 'political tinge' and supported this by noting that it was 'formed of people who are at one and the same time Judges and Politicians'. ${ }^{92}$ Patrick McGilligan asked his radio audience in 1930:

86 The Irish government listed Mr Justice FitzGibbon, a Protestant judge who formed one of the three members of the Irish Supreme Court, among those who opposed the Irish appeal to the Privy Council: NAI, Department of the Taoiseach, S4285A, memorandum of the Imperial Conference of 1930, undated. These claims rest on purported statements made by FitzGibbon during the debates on the Constitution of the Irish Free State in 1922. Analysis of his contributions to these discussions does not evince any obvious hostility to the Privy Council appeal. For example, see Dáil Debates, vol 1, cols 1406-07 (10 October 1922).

87 Eg, see Dáil Debates, vol 32, cols 667-68 (31 October 1929).

88 Douglas' intervention was a response to the letter to the press written by the Church of Ireland Archbishops during the Imperial Conference of 1930. This letter was published in The Times (7 November 1930).

89 Sunday Independent (9 November 1930). See also (1931) 82 Round Table 402.

90 TNA-PRO CAB 32/88 E (IR) (30) 8th meeting, 21 October 1930.

91 The office of Lord Chancellor was finally reformed by the Constitutional Reform Act 2005.

92 UCD Archives, Costello Papers, P190/94, notes on the memorandum prepared for the Imperial Conference of 1926 on appeals to the Privy Council, undated. See also Hughes (n 64) 104-05. 
Are not the British government and parliament still in a position to interfere in Irish affairs through this purely British Court, the majority of whose judges have most violently opposed the liberation of the Irish people? ${ }^{93}$

These suspicions filtered down to opinion pieces in Irish periodicals in which the Privy Council was described as the 'pocket tribunal of the English political party in power'. ${ }^{4}$ The Irish appeal to the Privy Council was dogged by conspiracy theories throughout its lifetime. One example was the rumour that the Judicial Committee had granted leave to appeal in Lynham $v$ Butler on the erroneous assumption that the case would affect a considerable number of Anglo-Irish landlords. ${ }^{95}$

Fears of clandestine subversion received public expression in Patrick McGilligan's radio broadcast of 1930. McGilligan warned his listeners of sinister elements who wished to use the Privy Council appeal 'as a means of keeping Ireland a pawn in British party politics and of preventing Irish ex-Unionists from becoming an inseparable element of the Irish nation'. According to McGilligan, attempts were being made through 'a well-subsidised Press and other means to maintain a feeling of discontent amongst the small ex-Unionist population of the Irish Free State'. Behind it all were 'enemies of the Irish people' who were 'violently opposed to the Treaty, and if they were strong enough to-day they would reduce them to subjection once more'. 96 In a subsequent newspaper article, McGilligan characterised support for the retention of the appeal as a 'sinister and disloyal campaign'. He asked his readers 'Is it the desire of the Protestant population of our country to become part of the warp and woof of the Irish nation?' McGilligan took the controversy over the appeal to a new level when he concluded: 'Is there not at the back of the demand the desire that the appeal to the Privy Council might one day be used as an indirect means for bringing the British back to Ireland?'97

\section{The 'cleaning of the slate' negotiations}

Claims that the Privy Council appeal offered a vital safeguard to Irish Protestants received significant attention outside Ireland. The issue was raised at successive Imperial Conferences in the 1920s and 1930s. The protection of the Protestants of the Irish Free State also encroached into the debates that preceded the enactment of the Statute of Westminster. The Imperial Conference of 1926 had decided that changes should not be made to the Privy Council appeal in any one Dominion without prior consultation and

93 UCD Archives, McGilligan Papers, P35B/108, radio broadcast, 9 November 1930.

94 Donal McEgan, 'John Bull's Privy Council' (1933) 23 The Catholic Bulletin 739.

95 Hughes (n 64) 99.

96 UCD Archives, McGilligan Papers, P35B/108 and NAI, Department of the Taoiseach, S4285B, transcript of radio broadcast of 9 November 1930 .

97 McGilligan (n 23) and UCD Archives (n 23). 
discussion with other members of the Commonwealth. ${ }^{98}$ For its part, the Irish government sought to win Dominion support for its position on the appeal in order to place pressure on its British counterpart. Arguments based on the success of the Irish government in thwarting Privy Council appeals and on fears of external subversion were designed to appeal to an Irish audience and were ill-suited to the collegial proceedings of an Imperial Conference. The argument that safeguards for Irish Protestants were not necessary was heavily intertwined with the claim that the minority community of the Irish Free State did not actually desire an appeal to an external tribunal. This offered the most promising approach to achieving external agreement for abolition of the appeal. Although this argument was raised without success during the Imperial Conferences of 1926 and 1930, the Irish government had good reason to believe that a series of Anglo-Irish negotiations initiated in 1931 held out greater promise of success.

In 1931 the minority Labour government in London was pre-occupied with the task of ensuring that the Statute of Westminster Bill passed through Parliament without substantial amendment. This historic piece of legislation was the response to demands for greater autonomy from some of the self-governing Dominions of the empire, such as Canada, South Africa and the Irish Free State. ${ }^{99}$ The original Bill was based on a wording that had finally been agreed at the Imperial Conference of 1930. Amending the agreed text would require reopening negotiations with the Dominions. This would endanger the survival of the Statute of Westminster and of the British government itself.

The most serious threat to the agreed text concerned the application of the proposed Statute of Westminster to the Irish Free State. Determined efforts were made within the British Parliament to ensure that the greater autonomy offered by the Statute of Westminster could not be used to abolish the Irish appeal to the Privy Council. The number of Irish Protestants at Westminster was relatively small. Yet, they represented a body of opinion that could never be entirely ignored. 100 The position of the Southern Protestants left behind in the Irish Free State was an emotive cause that was capable of garnering widespread support if properly harnessed. In early 1931 the Irish government seemed set

98 Cmd 2768 19-20. This reflected the views of the New Zealand delegation to the 1926 conference which refused to admit that any one Dominion had the right to abolish the Privy Council appeal without the consent of the others. TNA-PRO CAB 32/56 E(IR-26) 4th Meeting, 2 November 1926. It should be noted that the conference report of 1926 also stated 'it is no part of the policy of His Majesty's Government in Great Britain that questions affecting judicial appeals should be determined otherwise than in accordance with the part of the Empire primarily affected' (Cmd 2768 19). In reality, this statement provided nothing that had not been said to the Irish by British politicians during the constitution negotiations or by the Privy Council itself when dealing with Irish appeals. For example, see the comments made by Viscount Haldane when hearing the three petitions, Alexander E Hull and Co v Mary A E M'Kenna; The Freeman's Journal' Ltd v Erik Fernstrom and The Freeman's Journal' Ltd v Follum Traesliberi [1926] IR 402, 404. A B Keith referred to this statement as 'the usual, it must be feared insincere, declaration'. Arthur Berriedale Keith, Responsible Government in the Dominions, vol II (Clarendon Press 1928) 1230. Keith believed that the significance of this statement was nullified by the recognition that changes should not be made with respect to the appeal without prior consultation and discussion with other members of the Commonwealth. He concluded that this requirement stated in plain words that 'if Canada did not desire to change - and in the face of Quebec this must be Mr. King's attitude [W L M King, Prime Minister of Canada] - nothing had better be done': ibid.

99 Australia only adopted the operative provisions when its Parliament passed the Statute of Westminster Adoption Act 1942. New Zealand finally adopted the operative provisions of the Statute of Westminster in conjunction with the abolition of its upper house in 1947. The New Zealand Parliament passed the Statute of Westminster Adoption Act 1947 and the New Zealand Constitution (Request and Consent) Act 1947 received the royal assent on 10 December 1947. The latter measure was supplemented by the New Zealand Constitution (Amendment) Act 1947 passed at Westminster.

100 Eg, Sir Claude Schuster wrote that Lord Danesfort was 'a most stubborn and unreasonable person': TNAPRO LCO 2/910, C Schuster to N M Butler, 7 November 1930. 
on a policy of unilateral abolition of the Privy Council. ${ }^{101}$ The British feared that any such action would garner support for those who argued that the rights of Irish Protestants were being threatened. An agreed settlement on this issue might avert the impending crisis. The British government now focused on the claims made by their Irish counterparts that the Southern Protestant community of the Irish Free State did not value the Privy Council appeal and would not raise serious opposition to its abolition. ${ }^{102}$ If these claims could be verified, an agreed settlement on the Privy Council appeal might become a real possibility and the threat to the Statute of Westminster averted.

In early 1931 the British government asked the Irish if evidence could be provided to support their claims as to Southern Protestant opinion with respect to the Privy Council appeal. If such evidence could be produced in a form that could be presented to Parliament, the abolition of the Irish appeal might form part of a wider settlement on outstanding legal difficulties between the United Kingdom and the Irish Free State. ${ }^{103}$ The Irish agreed to postpone the introduction of legislation abolishing the appeal in order to explore the feasibility of this solution. ${ }^{104}$ This signalled the beginning of negotiations on a proposed settlement that soon acquired the charming soubriquet of the 'cleaning of the slate' agreement. A wide range of issues was proposed for inclusion in this draft agreement. These included the settlement of a territorial dispute between Northern Ireland and the Irish Free State over Lough Foyle, the inter se operation of international conventions between the United Kingdom and the Irish Free State, the surrender of fugitive offenders, mutual enforcement of judgments and court orders, the use of the Great Seal, the sealing of probates, Irish lights, estates of persons of unsound mind, execution of criminal warrants, maintenance and bastardy orders, repatriation of paupers, and matters concerning cables and wireless facilities. ${ }^{105}$ However, the dominant issue in the entire 'cleaning of the slate' agreement was always the search for a bilateral agreement on the appeal to the Privy Council. The fate of the entire agreement was dependent on the Irish government producing solid evidence that the Southern Protestant community in the Irish Free State did not desire the continuance of the appeal.

\section{Gauging Protestant support for the Privy Council appeal}

Given the importance placed on this issue, it is now necessary to examine the level of support for the Privy Council appeal among Southern Protestants in 1931. There are formidable obstacles in doing this. The Protestant minority was thinly scattered over the entire territory of the Irish Free State. The political views of its members were and remain notoriously difficult to pin down. Many could be accurately described as 'Southern

101 Dáil Debates, vol 37, col 1620-21 (18 March 1931).

102 Eg, see UCD Archives, McGilligan Papers, P35B/115, Walshe to McGilligan, undated; NAI, Department of the Taoiseach, S6164, report on meeting between Dulanty and Batterbee, 6 March 1931; and TNA-PRO LCO 2/910, Dominions Secretary to Attorney General, 2 March 1931, and note by Sir H Batterbee and Mr Machtig, 27 February 1931.

103 TNA-PRO LCO 2/910, CP 120(31), The Irish Free State and Appeals to the Judicial Committee of the Privy Council. See also TNA-PRO LCO 2/1231, undated memorandum attached to a letter from Sir Henry Batterbee to Sir Claude Schuster, 21 March 1931, and UCD Archives, McGilligan Papers, P35/167, undated British communiqué marked 'Secret'.

104 TNA-PRO LCO 2/910, CP 120(31), The Irish Free State and Appeals to the Judicial Committee of the Privy Council.

105 The draft forms of the proposed agreement can be found in TNA-PRO LCO 2/1231. An agreement over the position of the Ulster King at Arms was also suggested during the negotiations on the 'cleaning of the slate' agreement: TNA-PRO DO 35/127/7 file 4431/9, negotiations with the Irish Free State, 30 April 1931. A detailed treatment of the proposed 'cleaning of the slate' agreement can be found in Thomas Mohr, 'The Irish Free State and the Legal Implications of Dominion Status’ (unpublished thesis, UCD 2007) 99-149. 
Unionists' while the appellation was inappropriate and even offensive to others. Southern Protestants were understandably reticent to speak freely to strangers on sensitive political questions. A referendum confined to the Protestant community of the Irish Free State was obviously out of the question. Yet, the British were never so unrealistic as to ask for evidence of this nature. A memorandum drafted by the Dominions Office that was communicated to the Irish government suggested that 'the position that the Southern Unionists no longer desire the retention of the appeal' might be illustrated by means of 'a resolution in the Dáil or otherwise'. ${ }^{106}$ This suggestion assumed that the attitudes of Protestant members of the Dáil, or more accurately the Protestant members of the Oireachtas given the large representation in the Seanad, reflected those of the wider Protestant community in the Irish Free State. Nevertheless, the task of discovering the attitudes of the Protestant members of the Oireachtas involved asking no more than two dozen individuals. This was not an unrealistic undertaking and the Irish government already had a head start. The Irish government had long anticipated the need to provide some form of evidence that there was no significant support for the Privy Council appeal among the Southern Protestant community. In late 1930 or early 1931 the Irish government initiated a quiet process of consulting the Protestant members of the Oireachtas in order to learn their views on the Privy Council appeal and to search for a means of making these views clear to the British.

The consultation process was entrusted to two Protestant senators who supported the policies of the Irish government with respect to the Privy Council. James Douglas had earned the respect of members of the Irish government through his work with the White Cross during the War of Independence. ${ }^{107} \mathrm{He}$ was on close terms with Michael Collins and was a member of the committee charged with drafting the Irish Constitution in 1922. Samuel L Brown, a senator and barrister, undertook the bulk of responsibility for this process of consultation. Brown was assisted by Senator Andrew Jameson at a later stage of the consultation process. Jameson had been a member of the delegations that had spoken on behalf of the Southern Protestant community during the negotiations that preceded the signing of the 1921 Treaty and the enactment of the 1922 constitution. Brown and Jameson had formerly been strong supporters of the Privy Council appeal. They had both formed part of a delegation in 1929 that had delivered a formal protest to W T Cosgrave on the government's policy with respect to the appeal. ${ }^{108}$ The basis for the 'road to Damascus' travelled by both men over the intervening year is difficult to trace. The final conclusion of the fiasco surrounding the transferred civil servants ${ }^{109}$ together with the inefficacy of the Privy Council's decision in Performing Right Society v Bray Urban District Council are likely to have influenced their conversion. ${ }^{110}$ Whatever their motivations were, the Irish government's position that the minority community was not in need of external safeguards was greatly enhanced by the support of such individuals. Yet, as Douglas, Brown and Jameson were to

106 TNA-PRO LCO 2/1231, undated memorandum attached to a letter from Sir Henry Batterbee to Sir Claude Schuster, 21 March 1931, and UCD Archives, McGilligan Papers, P35/167, undated British communiqué marked 'Secret'.

107 Gaughan (n 39).

108 TNA-PRO LCO 2/910, statement of 10 December 1929 attached to letter from Archbishop of Dublin to Prime Minister, 27 September 1930.

109 Wigg and Cochrane v The Attorney General of the Irish Free State [1927] IR 293 (High Court), [1925] 1 IR 149 (Supreme Court) and [1927] IR 285 (Privy Council) and In re Compensation to Civil Servants under Article X of the Treaty [1929] IR 44.

110 [1928] IR 506 and [1930] IR 509. Senator Brown was broadly supportive of the enactment of the Copyright (Preservation) Act 1929, which was passed to prevent the appeal in this case: Seanad Debates, vol 12, col 988 (3 July 1929). 
discover, not all of their co-religionists agreed with their conclusions as to the value of the Privy Council appeal.

In January 1931 Douglas and Brown gave preliminary reports on their assessment of Protestant opinion in the Oireachtas. Douglas reported: 'Most of the people, to whom we are likely to appeal would favour an appeal to the Privy Council in important cases if this were practical politics.' He added 'there is no doubt that in a general way they mostly disapprove of the government's policy with regard to appeals'. Douglas concluded that in his opinion there would be more likelihood of strong opposition to the introduction of a Bill designed to block an appeal in a particular case, such as had occurred with respect to Lynham $v$ Butler, than a general abolition of the appeal by means of amending Article 66 of the constitution. ${ }^{111}$ Senator Brown agreed with Douglas' assessment but added the warning that the emergence of future controversies might radicalise Protestant opinion. Brown noted that there was a case currently under consideration in the Irish courts, Moore v Attorney General or the Erne fishery case, that showed every sign of forming a future appeal to the Privy Council. This legal challenge, supported by the state, to property rights held by members of the Protestant community had the potential to augment support for the appeal. Brown's warning proved prophetic and in just over two years the bitter struggle surrounding the Erne fishery case would prove to be the decisive climax of the entire dispute over the Privy Council appeal. ${ }^{112}$

In the spring of 1931 the Irish government entrusted Brown with the task of carrying out a general consultation with Protestant members of the Oireachtas. His task was to assess whether they might be prepared to subscribe to a resolution on the question of Privy Council appeals. The government also gave some thought as to what form such a resolution might take. It was obvious that passing an official resolution through both Houses of the Oireachtas would not be a suitable course of action. An official resolution would have to be tailored to meet the views of the majority of all members of the Oireachtas rather than the views of its Protestant members. Instead, the government hoped that a series of informal conferences would see the members of the 'Independent Groups in the Dáil and Senate' pass some form of unofficial resolution. In June 1931 a group of Independents from both Houses of the Oireachtas had an informal conference to gauge their views on the Privy Council appeal. A report was written on the conclusions of this conference that was intended to form the basis of a final resolution to be passed by Protestant TDs and senators. ${ }^{113}$

The report began by recognising that: 'The majority of those present at this conference are opposed to the abolition of the right of appeal to the Privy Council, and desire that if possible it should be preserved.' Having made this position clear, those consulted recognised that the appeal had already been made ineffectual in practice and that the Independent members of the Oireachtas were powerless to prevent its proposed abolition by means of legislation. The report went on to recognise the inevitability of change and, in these circumstances, urged that abolition be brought about through agreement with the British government in order to avoid the dangers resulting from an alleged breach of the 1921 Treaty. It concluded with a proposal that the Protestant members of the Oireachtas should approach the Irish Minister for External Affairs to urge him to attempt to bring about the proposed change by agreement with Great Britain. It was made clear that any such resolution would reiterate the point that the majority of the relevant members of the Oireachtas remained opposed to the abolition of the appeal to the Privy Council in principle. The proposed resolution would add that these representatives felt duty-bound to

111 UCD Archives, McGilligan Papers, P35/166, undated memorandum by Senator James Douglas.

112 UCD Archives, McGilligan Papers, P35/166, undated memorandum by Senator Samuel L. Brown.

113 UCD Archives, McGilligan Papers, P35/166, memorandum re Privy Council appeals, 17 June 1931. 
oppose any unilateral legislation seeking abolition. Nevertheless, these members of the Oireachtas would have expressed their willingness to accept abolition as a fait accompli in the event of an Anglo-Irish agreement on this matter. If this proved possible, the persons concerned would limit their criticism in the Oireachtas to 'an expression of regret that, in spite of the wishes of a large section of the Minority on the subject, the Government had not been willing to continue the right of appeal to the Privy Council'. 114

As events transpired, the proposals enshrined in this proposed resolution were never initiated. It seems likely that the Irish government was uncomfortable with many aspects of it. The strong expression of support in principle for the continuance of the Privy Council appeal was at total variance with the government's contention that Southern Protestants placed no value on the appeal. Moreover, the proposed resolution made it clear that the position of its adherents was based on their recognition that the appeal had already been rendered ineffective by the Irish government and also on the basis of their own powerlessness to prevent abolition by unilateral means. These admissions gave a definite impression of acquiescence under duress, an impression that would not have been lost upon Unionists at Westminster. In addition, the strong expression of opposition to unilateral abolition could not have been comfortable reading to a government that was determined to follow this course in the absence of bilateral agreement and had already drawn up the legislation required to bring it into effect. ${ }^{115}$ However, the final nail in the coffin of the proposal does not seem to have come from the Irish government but from the Southern Protestants themselves.

A list of the senators who were consulted by Brown on the Privy Council appeal has survived. The list includes his own name along with those of Douglas and Jameson. It also shows that Brown consulted Sir John Griffith, Henry Guinness, The McGillicuddy, John Bagwell, Arthur Vincent, Sir Edward Biggar and the Countess of Desart. ${ }^{116}$ The addition of the last name is interesting because the Countess of Desart was not a Protestant but belonged to the Jewish faith. However, the list does expressly mention that Brown had not consulted two senators, Sir John Keane and William Barrington. No reason is given for ignoring these two senators but subsequent events illustrate that Keane was certainly a supporter of the appeal to the Privy Council. Keane was one of those who objected most strenuously to abolition when de Valera finally put it into practice in $1933 .{ }^{117}$ It is possible that Keane's views had been radicalised in 1933 by the dispute over the Erne fishery case, as had been predicted by Brown. Nevertheless, Keane's omission from the consultation process is strongly suggestive of a perception that he and Barrington were not seen as likely supporters of the intended resolution.

Notwithstanding the doubts that might have surrounded Senators Keane and Barrington, there was certainly strong opposition to the draft resolution among members of the Dáil. No list of the TDs who were consulted appears to have survived. Nevertheless, W $\mathrm{T}$ Cosgrave wrote that three 'northern deputies were violently opposed to the

114 Ibid.

115 NAI Department of Foreign Affairs, 3/1, draft Bills.

116 This list has survived in two sources. It was written on the back of the document entitled 'memorandum re Privy Council appeals', 17 June 1931, and on an envelope containing a letter from Cosgrave to McGilligan, dated 26 June 1931. The author found both of these when the original documents were still accessible to members of the public in UCD Archives (at this time they were archived under McGilligan Papers, P35/196). These files have since been re-organised under the new reference of McGilligan Papers, P35/166. Public access is now limited to microfilm copies that do not reproduce these important lists. Archivists take note!

117 Seanad Debates, vol 17, col 1681 (31 October 1933). 
proposal'. ${ }^{118}$ It is difficult to identify these persons with total certainty, but it is likely that these were Major James Sproule Myles, John James Cole and Alexander Haslett. These Southern Protestants were, respectively, TDs for Donegal, Cavan and Monaghan. Myles was a retired officer from the Royal Inniskilling Fusiliers and had served as a Unionist MP at Westminster, Cole came from a Protestant farming background while Haslett, another farmer, had been endorsed by the Orange Order in the first election of $1927 .{ }^{119}$ It is possible that the opposition to the abolition of the appeal extended beyond these three 'northern deputies'. When de Valera sought to abolish the appeal in 1933 his most vocal opponents in the Dáil were Professor William Edward Thrift and John Good. Thrift had grown up in England and represented Trinity College Dublin while Good was TD for Dublin County.

It is uncertain whether the proposed convention of the 'Independent Groups in the Dáil and Senate' might have delivered a majority of Protestant members of the Oireachtas in favour of the draft resolution on the Privy Council appeal. Even if it had, the presence of a vocal minority who, in Cosgrave's own words, were 'violently opposed' even to a limited form of acquiescence is indicative of the strength of feeling on the Privy Council issue among certain sections of the Protestant community. It was a situation that was completely at variance with the claims made by Irish officials to their British counterparts that none of the Southern Protestants in the Dáil would oppose abolition. ${ }^{120}$ Even if the proposed resolution had been acceptable to the Irish government and even if a majority of Protestant members of the Oireachtas had given it their support, it is possible that the opposition of a determined minority might have been enough to rally Unionist sympathy at Westminster.

The failure of the proposed resolution did not mean that the Irish government had given up on the search for a bilateral settlement. It explored other means of indicating Protestant acquiescence to the abolition of the Privy Council appeal. The preferred alternative was to offer the British the testimony of notable Southern Protestants as to the feelings of their co-religionists in the Irish Free State as a whole. This task fell to Senators Brown and Jameson who travelled to London in September 1931 and secured an interview with the Dominions Secretary, James Thomas.

The two Irishmen met the Dominions Secretary on 17 September 1931. Brown and Jameson were keen to stress the fair treatment of the minority by the Irish government. The two senators declared that they had no complaints and went as far as to claim that there was no longer any 'religious question' in the Irish Free State. ${ }^{121}$ Brown and Jameson stated that the Southern Unionists could be divided into three classes on the specific question of the Privy Council appeal:

1 There was the class of those who regarded the appeal as futile and an irritant to good relations between the Protestant minority and the rest of the population of the Irish Free State, and who, on that ground, were in favour of its immediate abolition;

2 There was a second class, who, while regretting the disappearance of the appeal, recognised that the Irish Free State government was committed to

118 UCD Archives, McGilligan Papers, P35/166, Cosgrave to McGilligan, 26 June 1931.

119 Bowen (n 73) 52-53. See also the database of Oireachtas members at <www.oireachtas.ie/membershist/default.asp?housetype $=0>$ accessed 6 July 2011.

120 TNA-PRO LCO 2/910, CP 120(31) The Irish Free State and Appeals to the Judicial Committee of the Privy Council.

121 TNA-PRO DO 35/127/7 file 4431/20, note of interview between Mr Thomas and Senator Brown and Senator Jameson, September 1931. 
securing its abolition. They thought that it should come by agreement with the United Kingdom government;

3 There was a third class who was opposed to abolition in any shape or form.

Brown and Jameson admitted the difficulties in gauging the opinions of Protestants throughout the Irish Free State. Nevertheless, they were prepared to offer their own estimations of Protestant opinion on the Privy Council appeal. They began by noting that among 'the thinking and educated people' the majority belonged to the first class. Senator Brown added that this category included members of the governing body of Trinity College Dublin. Nevertheless, Brown and Jameson were prepared to concede that a larger proportion of the Southern Protestants probably belonged to the second class. In their opinion the number belonging to the third class in the Irish Free State was small and largely confined to the border counties. This claim may have reflected the position of the three 'northern deputies' in the Dáil mentioned by Cosgrave. Brown and Jameson did note, however, that eruption of controversy in the near future might arouse old prejudices and have the effect of driving some of the Southern Protestants out of the second class of opinion and into the third. ${ }^{122}$

As for opinions within the Oireachtas, the senators stated that of the 11 or 12 representatives of the minority in the Seanad, all belonged to the first class. They added that of the 11 representatives of the minority in the Dáil, three belonged to the first class and eight to the second class. Although the two senators might be expected to be on firmer ground with respect to Protestant opinion in the Oireachtas than with respect to the Irish Free State as a whole, these figures are open to serious question. Their claim that Protestant senators were all of the opinion that the Privy Council appeal was an irritant and should be abolished immediately is particularly dubious. These views do not reflect the conclusions of the informal consultations with Protestant members of the Seanad and Dáil in June 1931 that had made it clear that a majority favoured the retention of the appeal in ideal circumstances. The lack of consultation with Senators Keane and Barrington has already been noted. The figures given with respect to the Dáil are even more questionable. It should be recalled that the proposed resolution, which would have expressed support for the appeal while acquiescing in a position of bilateral abolition, was 'violently opposed' by at least three unidentified 'northern deputies'. ${ }^{23}$ The staunch opposition of these persons surely placed them in the third class of Southern Protestants.

The testimony offered by Brown and Jameson did not result in the anticipated bilateral agreement that would have paved the way for the abolition of the Privy Council appeal. The opinions offered by the two senators were not sufficient to satisfy the criteria suggested by the original British proposal. ${ }^{124}$ First, the opinions of the two senators did not constitute evidence that could be shown to those in the United Kingdom who professed to sympathise with the Protestants of the Irish Free State. Second, the British government may not have been entirely convinced by their testimony. Senators Brown and Jameson were among those who saw the appeal as 'futile and an irritant' and as such were, by the admission of their own evidence, unrepresentative of the majority of Southern Protestants. As shown above, there was certainly good reason to doubt the accuracy of some of the evidence provided by them.

122 Ibid.

123 UCD Archives, McGilligan Paper, P35/166, memorandum re Privy Council appeals, 17 June 1931.

124 See TNA-PRO LCO 2/1231, undated memorandum attached to letter from Sir Henry Batterbee to Sir Claude Schuster, 21 March 1931, and UCD Archives, McGilligan Papers, P35/166, undated British communiqué marked 'Secret'. 
There are definite indicators that suggest that Southern Protestant support for the Privy Council appeal was far more substantial than the Irish government was prepared to admit. Two major Protestant institutions gave unwavering support to the Privy Council appeal throughout the 1920s and 1930s. The first was the Irish Times, the main newspaper read by the minority community, which repeatedly stressed the importance of the appeal to the minority community and consistently condemned the efforts of the Irish government to dilute its effectiveness. ${ }^{125}$ The second was the Church of Ireland. In late 1929 the Standing Committee of the General Synod of the Church of Ireland decided to send a delegation to interview President Cosgrave on the Irish government's declaration that it intended to seek the abolition of the appeal at the Imperial Conference of 1930. This delegation included representation from a third Southern Protestant institution, Trinity College Dublin.

On 10 December 1929 a delegation consisting of the Church of Ireland Archbishop of Dublin, the Provost of Trinity College Dublin, Edward John Gwynn, together with Senators John Bagwell, Samuel L Brown and Andrew Jameson met with Cosgrave to discuss the Privy Council appeal. ${ }^{126}$ The delegation read out a prepared statement of protest on behalf of the minority community at the policy of the Irish government towards the Privy Council appeal. The statement 'most respectfully' protested the policy of the Irish government and made clear that 'the minority which we represent must not be taken as acquiescing therein'. ${ }^{127}$ Indeed, the deputation sought to 'impress on the President of the Executive Council the fact that there is a feeling of grave disappointment - we might even say of alarm, on the part of those whom we represent'. ${ }^{128}$ 'The efforts of the delegation to impress the strength of their objections on Cosgrave were not successful. Cosgrave recounted, almost two years after the meeting, that the delegation had been resigned to the position that the Privy Council appeal was bound to be abolished and, consequently, had focused on securing an enlargement of the Supreme Court as an alternative safeguard. ${ }^{129}$

The failure to impress the seriousness of objections to government policy on Cosgrave's mind at the meeting of 10 December 1929, either through poor communication or lapse of memory, had serious consequences. It had a profound influence on the Irish government's reaction to a letter to The Times written by the Church of Ireland Archbishops of Armagh and Dublin at the time of the Imperial Conference of 1930.130 Although the letter did little more than repeat the concerns raised with Cosgrave the previous year, the Irish government seemed to regard it as a bolt from the blue. The government refused to consider the letter as a genuine protest and preferred to regard the Archbishops as proxies in the hands of the British government. ${ }^{131}$ This is yet another example of the conspiracy theories that resulted from the breakdown in relations between the Irish government and the Judicial Committee of the Privy Council. In fact, the initiative behind this intervention came from the Archbishops

125 Eg, see Irish Times (19 February 1929). The Irish Times condemned the Irish practice of passing ad hoc legislation to block appeals as a 'standing protest against the Free State's membership of the British Empire, and a warning to the English people that the Saorstát will secede at the earliest opportunity': Irish Times (11 April 1930).

126 Brown and Jameson had not yet come to the conclusion that the appeal was 'futile and an irritant' at this point.

127 TNA-PRO LCO 2/910, statement of 10 December 1929 attached to letter from Archbishop of Dublin to Prime Minister, 27 September 1930.

128 Ibid.

129 NAI, Department of the Taoiseach, S4285A, Michael McDunphy to Diarmuid O’Hegarty, 8 November 1930.

130 The Times (7 November 1930).

131 See NAI, Department of the Taoiseach, S4285B, Diarmuid O'Hegarty to Michael McDunphy, 7 November 1930 and W T Cosgrave to Lord Granard, 8 November 1930. 
themselves. ${ }^{132}$ The British government had actually considered the Archbishops' letter to be an unhelpful intervention and had opposed its publication in the press. ${ }^{133}$

\section{The Statute of Westminster}

The failure to provide evidence of Southern Protestant consent or acquiescence to the abolition of the Privy Council appeal undermined the keystone of the 'cleaning of the slate' agreement. By the middle of 1931 the negotiations had petered out. Unilateral means of abolishing the appeal returned to the forefront of the agenda of the Cumann na nGaedheal government led by W T Cosgrave. Draft legislation to achieve this goal was prepared and members of the Oireachtas were assured that it would be introduced in the near future. ${ }^{134}$ However, the introduction of this legislation was delayed for reasons that have never been made clear. The most likely explanation for this delay was the need to avoid disrupting the passage of the Statute of Westminster through the British Parliament in late 1931. The Irish Free State had much to gain from the augmentation of Dominion autonomy offered by this historic piece of legislation. It was imperative to avoid rocking the boat on Privy Council appeals during this sensitive period of time.

Those who professed to sympathise with the Protestant community of the Irish Free State were determined to insert special provisions into the Statute of Westminster Bill to ensure the continuance of the Irish appeal to the Privy Council. Lord Danesfort, ${ }^{135}$ himself a Southern Protestant, introduced an amendment to this effect during the Bill's passage through the House of Lords. ${ }^{136}$ Danesfort was convinced that the Privy Council was an effective safeguard for Southern Protestants and made it clear that his actions were motivated by concern for the position of his co-religionists in the Irish Free State. ${ }^{137}$ Despite impassioned argument, this proposed amendment never had any real chance of acceptance. The British government made it clear that amendment of the agreed text of the

132 The archbishops wrote to the Dominions Secretary, J H Thomas, on 27 September 1930, outlining the arguments that were later used in their letter to The Times. The letter ended with an appeal to Thomas to resist any proposal to limit what they saw as a constitutional right granted by the Treaty: TNA-PRO DO 35/88, 4002/3 and LCO 2/910, Archbishop of Dublin to Prime Minister, 27 September 1930. The British government was given the text of their letter to The Times three days before publication: TNA-PRO DO $35 / 88,4002 / 5$.

133 TNA-PRO LCO 2/910, C Schuster to N M Butler, 7 November 1930.

134 Dáil Debates, vol 37, cols 1620-21 (18 March 1931).

135 John Butcher (1853-1935) Baron Danesfort, of Danesfort in the County of Kerry was the second son of Samuel Butcher, Bishop of Meath.

136 Danesfort's amendment would have inserted the following provisions into the Bill: 'Without prejudice to maintenance of the other provisions of the Treaty of sixth December, nineteen hundred and twenty-one, and of the Irish Free State (Agreement) Act 1922, and of the Irish Free State Constitution Act 1922, it is hereby declared that nothing in this Act shall be deemed to authorise the Parliament of the Irish Free State to alter or repeal Section two of the said Treaty or the provisions contained in the Irish Free State Constitution Act 1922, as to the right of any person to petition His Majesty for leave to grant such leave.' : HL Deb 1 December 1931, vol 83, col 231. Danesfort's amendment was, in many respects, a poorly drafted provision. The reference to the 'Supreme Court of Southern Ireland' was an unfortunate, if not untypical, error. There was no such legal entity as 'Southern Ireland' in existence in the 1930s. The reference to the Articles of Agreement of 1921 as 'the Treaty' was particularly regrettable given the insistence of successive British governments on the legal nature of this instrument. Even though British officials, for the sake of convenience, often referred to the agreement reached in 1921 as 'the Treaty', their official position was that it was nothing of the sort in strict legal terms. For a discussion of this issue, see Henry Harrison, Ireland and the British Empire (Robert Hale \& Co 1937) 131-70.

137 HL Deb 1 December 1931, vol 83, cols 232-23. Danesfort supported his claim that the appeal was an effective safeguard by pointing to the final outcome of the appeals concerning the transferred civil servants. See Wigg and Cochrane v The Attorney General of the Irish Free State [1927] IR 285 and In re Compensation to Civil Servants under Article $X$ of the Treaty [1929] IR 44. 
Statute of Westminster would never be acceptable to the Dominions. ${ }^{138}$ The leader of the Conservative Party in the House of Lords, Lord Hailsham, ${ }^{139}$ also stressed that acceptance of the amendment would damage Anglo-Irish relations and would also have wider ramifications throughout the Commonwealth. ${ }^{140}$ Even Lord Midleton, a leading Southern Unionist who had lobbied for safeguards for the Protestant community during the negotiations on the 1921 Treaty and the 1922 constitution, failed to support Danesfort's initiative. Midleton did not underestimate the determination of the Irish government on this issue. He told the House of Lords that even if the amendment were passed it would prove ineffective, as 'We all know that we are not going by force of arms to reaffirm the right of appeal to the Privy Council.' ${ }^{\text {141 }}$ The defeat of the amendment meant that all that Danesfort and his supporters could do was to call upon the leaders of the Irish government to pause before carrying out a measure that would be seen as a 'gross breach of faith'. ${ }^{142}$

\section{The abolition of the Privy Council appeal}

The Statute of Westminster was finally enacted without any major deviation from the text that had been agreed at the Imperial Conference of 1930. In February 1932 the Cosgrave government lost a general election in the Irish Free State and was replaced by a new Fianna Fáil government led by Eamon de Valera. The new administration promised a programme of constitutional reform that was far more radical than anything proposed by Cumann na nGaedheal. Ironically, this actually provided the Privy Council appeal with a short stay of execution. The removal of the controversial parliamentary oath was the priority issue for the new Irish government and this objective was not achieved until 1933. ${ }^{143}$ Then and only then, did the Fianna Fáil government introduce the Constitution (Amendment No 22) Bill into the Oireachtas, which aimed at abolishing the appeal to the Privy Council from the Irish courts.

De Valera had hoped that the constitutional amendment abolishing the appeal to the Privy Council would attract unanimous support in the Oireachtas. ${ }^{144}$ This hope was dashed when members of the minority community in the Oireachtas registered strong protests. Those who spoke against the constitutional amendment in the Dáil included Professor William Edward Thrift ${ }^{145}$ and John Good. ${ }^{146}$ Sir John Keane spoke against this measure in the Seanad. ${ }^{147}$ The most interesting intervention was that of Professor Thrift, a future Provost of Trinity College Dublin. 148 The strength of the intervention of a relatively passive TD who seldom spoke in the Dáil seemed to take the house by surprise. ${ }^{149}$ Thrift was incensed at the policy of successive Irish governments, which took for granted the support or acquiescence of the minority community with respect to opposition to the Privy

138 This had been recognised in the report of the Imperial Conference of 1926.

139 Douglas McGarel Hogg, Viscount Hailsham (1872-1950) was Lord Chancellor (1928-1929) and (1935-1938).

140 HL Deb 1 December 1931 vol 83, col 237-41.

141 Ibid col 244.

142 Ibid col 243.

143 Constitution (Removal of Oath) Act 1933.

144 Dáil Debates, vol 17, col 2116 (4 October 1933).

145 TD for Dublin University.

146 TD for Dublin County.

147 Dáil Debates, vol 17, col 1681 (31 October 1933).

148 Thrift was Professor of Natural and Experimental Philosophy (1901-1929) and Vice-Provost (1935-1937).

He was a TD for Trinity College Dublin (1922-1937) before he became the Provost of that university (1937-1942).

149 Irish Times (Dublin, 13 October 1933). 
Council. Thrift insisted that protests had been registered on every occasion on which the Irish appeal to the Privy Council had been attacked. ${ }^{150}$ He objected to the final abolition of the appeal on the basis that it had been part of a bargain concluded between the majority and minority communities that underpinned the foundation of the Irish Free State. ${ }^{151}$ Thrift emphasised that the Privy Council appeal had been one of a number of vital concessions that had won the acquiescence of Southern Protestants to the conclusion of the 1921 Treaty. He concluded that the minority community had honourably maintained its side of the bargain and that integrity of the majority community was now in doubt:

When concessions are made in a bond it is not an honest way of dealing with that bond immediately to set yourself out to remove from the bargain - because you have the power - anything that you do not like in that bargain. That is not the way I understand such a bargain at any rate ... Whittle away this concession and every other concession until you get the Treaty to the form in which you want it and what chance have you of making any bargain in the future with those who disagree with you? ${ }^{152}$

De Valera flatly denied the existence of the bargain asserted by Thrift. Arguments based on a betrayal of trust that were founded on the conclusion of the 1921 Treaty left him unmoved. ${ }^{153}$

The Irish government was far more concerned with opposition from a completely different quarter. The Privy Council granted leave to appeal the decision of the Irish Supreme Court in Moore v Attorney General while the Constitution (Amendment No 22) Bill was being debated in the Oireachtas. This appeal would give the Privy Council the opportunity to pass judgment on its own abolition with respect to the Irish Free State and on all the other constitutional amendments aimed at dismantling the settlement imposed by the 1921 Treaty. ${ }^{154}$ The Irish government attempted to prevent this by introducing the last in a long line of efforts to block Irish appeals to the Privy Council. This took the form of making the abolition of the Privy Council appeal retrospective in effect in the final text of the Constitution (Amendment No 22) Act 1933. ${ }^{155}$ The determination of the Privy Council to consider the appeal in defiance of these actions made it clear that the long-running dispute over Irish appeals still had at least one more round to run.

The decision of the Privy Council in Moore v Attorney General was finally delivered in 1935. The Judicial Committee unexpectedly upheld the validity of its own abolition in relation to the Irish Free State. The substance of the decision of the Privy Council was summarised in a single sentence:

150 Dáil Debates, vol 49, col 2389 (12 October 1933).

151 Dáil Debates, vol 49, cols 2389-90 (12 October 1933). Thrift made a similar argument during the debates on the Constitution (Removal of Oath) Act 1933. Dáil Debates, vol 41, cols 922-33 (29 April 1932).

152 Dáil Debates, vol 49, cols 2389-90 (12 October 1933).

153 Ibid col 2392.

154 At this point these included Constitution (Removal of Oath) Act 1933, Constitution (Amendment No 20) Act 1933, Constitution (Amendment No 21) Act 1933 and Constitution (Amendment No 22) Act 1933.

155 S 2 provides: 'The amendments made in this Act in Article 66 of the Constitution shall, in relation to judgements and orders pronounced or made by the Supreme Court before the passing of this Act apply and have effect in regard to the institution and prosecution, after the passing of this Act of an appeal or a petition for leave to appeal from any judgement or order and to the further proceeding after the passing of this Act of an appeal or a petition for leave to appeal from any judgement or order which was instituted before such passing.' 
The simplest way of stating the situation is to say that the Statute of Westminster gave to the Irish Free State a power under which they could abrogate the Treaty, and that, as a matter of law, they have availed themselves of that power. ${ }^{156}$

This surprising decision seemed to confound critics of the Judicial Committee of the Privy Council in the Irish Free State who questioned the objectivity of this court. Nevertheless, to many observers the abolition of the appeal and its confirmation by the Privy Council itself cut the final bonds between the United Kingdom and the Protestants of the Irish Free State. Ronald Ross, an Ulster Unionist MP, expressed his dismay that the Protestants who had decided to stay and keep their property in the Irish Free State on the basis of certain safeguards were 'now at the mercy of the courts of that country without appeal'. ${ }^{157}$ It is important to emphasise that suspicions as to the objectivity of the Judicial Committee of the Privy Council expressed by Irish Nationalists were matched by expressions of distrust by Unionists as to the objectivity of the courts of the Irish Free State. ${ }^{158}$ Yet, the dismay of Unionists at Westminster at the demise of the Irish appeal to the Privy Council seems to reflect deeper concerns. The United Kingdom was seen as having a special duty in maintaining the rights of the minority community. This was reflected in a number of unsuccessful attempts to amend the Statute of Westminster, sponsored by Winston Churchill and others, in order to safeguard the Privy Council appeal. ${ }^{159}$ It was a responsibility that was seen as important in maintaining a direct link between the United Kingdom and this minority community. This link was now seen as having been severed as a result of careless concessions granted to the Irish Free State by the Statute of Westminster that had been pushed through by a British government whose priorities did not include protecting the interests of the Protestants of the Irish Free State. ${ }^{160}$ If the term 'exUnionists' was not an accurate description of the views of Southern Protestants in 1935, there was now little to prevent it from becoming increasingly accurate in the future.

156 Per Sankey LC [1935] IR 472, 486-87 and [1935] AC 484, 499. This judgment was based on the assertion that the Irish 1922 constitution had been created by the Irish Free State Constitution Act 1922, an imperial statute passed at Westminster. The enactment of the Statute of Westminster had removed any fetters that might have been placed on the Irish Free State in terms of amending imperial legislation. This meant that the Oireachtas was capable of removing the provisions of the 1922 Act that demanded that all Irish laws be compatible with the 1921 Treaty. This had purportedly been done by means of the Constitution (Removal of Oath) Act 1933. Consequently, the Oireachtas was also capable of abolishing the appeal to the Privy Council under Constitution (Amendment No 22) Act 1922 notwithstanding questions of compatibility with the provisions of the 1921 Treaty. A detailed analysis of Moore v Attorney General can be found in Mohr (n 17).

157 HC Deb 20 June 1935, vol 303, cols 639-40.

158 Eg, see A B Keith, The Constitutional Law of the British Dominions (MacMillan 1933) 271-72.

159 One amendment, moved in the House of Commons by Colonel John Gretton, was aimed at maintaining the integrity of the entire Treaty settlement. From a British perspective, the Privy Council appeal was a key aspect of this settlement. The proposed amendment would have provided that: 'Nothing in this Act shall be deemed to authorise the Legislature of the Irish Free State to repeal, amend, or alter the Irish Free State Agreement Act, 1922, or the Irish Free State Constitution Act, 1922, or so much of the Government of Ireland Act, 1920, as continues to be in force in Northern Ireland.': HC Deb 24 November 1931, vol 260, col 303. The defeat of this amendment resulted in an attempt at amendment moved by Lord Danesfort that was aimed specifically at the Privy Council appeal. See n 136.

160 The British government had insisted in 1931 that the enactment of the Statute of Westminster would not permit the Irish Free State to dismantle the Treaty. For example, Stanley Baldwin told the House of Commons: 'I am advised by the Law Officers of the Crown that the binding character of the Articles of Agreement will not be altered by one jot or tittle by the passing of the Statute.': HC Deb 24 November 1931, vol 260, col 344. These words came back to haunt Baldwin in the aftermath of the Privy Council's decision in Moore v Attorney General: HC Deb 10 July 1935, vol 304, cols 439-47. 


\section{Conclusion}

The institution of the Seanad, university representation in the Dáil and the appeal to the Judicial Committee of the Privy Council were all perceived as safeguards for the Southern Protestant minority. By the middle of 1936 all these institutions had been removed from the Constitution of the Irish Free State. ${ }^{161}$ The provisions of Article 8 of the 1922 constitution $^{162}$ and the proportional representation voting system were left as isolated survivors of the undertakings that had been given to the Southern Protestant minority in the early 1920s. ${ }^{163}$ These developments led to predictable accusations of 'betrayal' at Westminster. This can be seen in the context of the abolition of the Privy Council appeal in 1933, which provoked Edward Carson, in one of his last speeches to the House of Lords, to deliver a political swansong resonant with unleavened bitterness:

All I can say ... is that every single promise we have made to the loyalists of Ireland has been broken, that every pledge of law and order has been destroyed, that everything that makes life and property safe has gone and now the last remnant is to be taken away. ${ }^{164}$

What conclusions can be drawn as to the relationship between the Protestants of the Irish Free State and the Privy Council appeal? As has already been noted, the political views of this community remain notoriously difficult to pin down. Even persons who were themselves members of that community admitted the difficulties of gauging the overall opinion of their co-religionists. ${ }^{165}$ Nevertheless, it is clear that most Protestant members of the Oireachtas disapproved of the Irish government's actions in blocking Privy Council appeals. This is evident from the informal consultations that took place in 1931. Senators Douglas and Brown warned of the danger of radicalising Protestant opinion if this policy was maintained, as it was with respect to the appeal in Moore v Attorney General. ${ }^{166}$

More importantly, it is clear that the extent and depth of Southern Protestant support for the appeal to the Privy Council from the Irish courts was consistently underestimated throughout the lifetime of that appeal. This consideration is evident in the flawed analysis of the opinions of Protestant members of the Oireachtas that was presented to the British government by Senators Brown and Jameson in 1931. The views of the delegation that visited W T Cosgrave in 1929 to protest the policy of his government with respect to the appeal proved to be words written on water. The letter written to the press by the Church of Ireland Archbishops in 1930 was written off as a ploy by proxies of a devious British

161 Constitution (Amendment No 24) Act 1936, Constitution (Amendment No 23) Act 1936, Constitution (Amendment No 22) Act 1933. Seán Lemass made the following remarks during the debates that preceded the abolition of the Free State Seanad: 'Is it not about time that the democracy of this country was taken out of the leading strings of that very small minority who previously had it in halters? ... If there is going to be a dictatorship in consequence of this measure, it will be a dictatorship of the majority of the Irish people ... If we abolish the veto of that [minority] group, if the Granards and the Jamesons and the like are no longer to be in a position to block the progress of the Irish nation . . .: Dáil Debates, vol 51, cols 1868-69 (18 April 1934). It should be noted that Lord Granard and Andrew Jameson were supporters of the abolition of the appeal to the Privy Council from the Irish courts.

162 Later substantially reproduced in Article 44 of the Irish Constitution of 1937.

163 Even proportional representation was threatened with replacement in referenda held in 1959 and 1968. It survived these challenges and has emerged intact into the twenty-first century.

164 HL Deb 6 December 1933, vol 90, col 335.

165 Senators Brown and Jameson admitted this in their interview with J H Thomas on 17 September 1931: TNAPRO DO 35/127/7 file 4431/20, note of interview between Mr Thomas and Senator Brown and Senator Jameson, September 1931.

166 UCD Archives, McGilligan Papers, P35/166, undated memoranda by Senators James Douglas and Samuel L Brown. 
government. The consistent stance of the Irish Times seems to have made little impact outside the readership of that newspaper.

The constant underestimation of support for the Privy Council appeal among the Southern Protestant community did come at a price. It was this consideration that led to the failure of the proposed resolution that was intended to show that Protestant members of the Oireachtas did not value the appeal, which, in turn, doomed the proposed 'cleaning of the slate' agreement. The same underestimation of support led Eamon de Valera to voice his expectation that abolition of the appeal would be passed by universal acclaim when the necessary legislation was finally presented to the Oireachtas. ${ }^{167}$ De Valera seemed genuinely surprised when embarrassing voices of opposition from the Southern Protestant community were raised.

All these considerations should cause the historian to hesitate before echoing the position asserted by representatives of Irish governments, who were by no means disinterested parties, and concluding that opposition to the abolition of the Privy Council appeal in the 1930s only came from 'a tiny vociferous, proportion of former Unionists'. 168 Nor is it safe to dismiss a position that was supported by the majority of the Southern Protestants at Westminster, by a significant number of Protestant members of the Oireachtas, by the Irish Times as the major newspaper of the minority community, by three successive Provosts of Trinity College Dublin ${ }^{169}$ and by the leaders of the Church of Ireland as the viewpoint of 'cranks' or 'a handful of extremists'. ${ }^{170}$

The attitude of the population of the Irish Free State to the Privy Council appeal as a whole is not open to dispute. There can be little doubt that the majority saw the appeal as a serious attack on national dignity and national sovereignty. On a similar theme, few people in living in the inter-war years would have disputed that relations between the majority and minority communities were far healthier in the Irish Free State than in neighbouring Northern Ireland. Yet, equally few have been able to endorse McGilligan's claim that Irish Catholics had 'never been guilty of religious intolerance'. ${ }^{171}$ De Valera's belief that 'this country knows nothing about religious persecution and intolerance' can be placed at the same level of hyperbole. ${ }^{172}$ Confident assertions by successive Irish governments that the overwhelming majority of 'ex-Unionists' rejected the need for an appeal to an external court supported the convenient conclusion that there was no real 'minority community' in the Irish Free State.

The ability of Irish ministers to 'look into the hearts' of Southern Protestants and so glean their political opinions was matched by a determination to abolish the Privy Council appeal even if, contrary to their divination, a majority of Southern Protestants turned out to be opposed to this course of action. W T Cosgrave deplored the contention that 'a minority of seven and a half per cent should be entitled to prevent the wishes of the remaining 92 and a half from being realised' with respect to the Privy Council appeal. ${ }^{173}$ In 1933 the abolition of the appeal was opposed in the Oireachtas on the basis that it violated

167 Dáil Debates, vol 17, col 2116 (4 October 1933).

168 Swinfen (n 24) 124.

169 John Henry Bernard (1919-1927), Edward John Gwynn (1927-1937) and William Edward Thrift (1937-1942).

170 TNA-PRO DO 35/127/7 Granard to Thomas, 20 August 1931, and McGilligan (n 23).

171 NAI, Department of the Taoiseach, S4285B, transcript of radio broadcast of 9 November 1930.

172 NAI, Department of Foreign Affairs, 3/1. De Valera wrote this in a draft speech that was intended to accompany the introduction of the Bill designed to abolish the Privy Council appeal in 1933.

173 NAI, Department of the Taoiseach, S4285B, Cosgrave to Granard, 8 November 1930. 
an unwritten 'bargain' between the majority and minority communities that underpinned the foundation of the state. Eamon de Valera responded in uncompromising terms:

If there are any bargains standing in the way of the sovereignty of our people they have got to go. That is our attitude at any rate, and that is the spirit in which I move that the Bill [to abolish the Privy Council appeal] do now pass. ${ }^{174}$

Over seven decades have passed since the abolition of the Irish appeal to the Privy Council. Today, Irish citizens can access a number of external tribunals in order to assert their rights. These include the European Court of Justice and the European Court of Human Rights. Yet, it is important to examine the history of the Irish appeal in the context of the early twentieth century and not that of the early twenty-first century. The circumstances in which the self-governing Irish state was created, together with the limitations on key areas of sovereignty that remained after 1922, did not create favourable conditions for the toleration of an external tribunal sitting in London. The appeal was seen as having been imposed on the Irish Free State by stealth and serious doubts as to the objectivity of this court gained wide currency in Irish political circles. The Irish Free State was far from unique in inter-war Europe in witnessing a conflict between assertions of national sovereignty and demands for the protection of the rights of vulnerable minorities. This article is not intended to pass judgment on this conflict and its final resolution. Its only purpose is to illustrate the existence of this conflict. This is necessary because its significance has, in the past, been dismissed without detailed investigation or, far more commonly, been ignored completely.

It is important to remember that the 'disappearance of Britain', the theme of this special issue of the Northern Ireland Legal Quarterly, first manifested itself in the secession of much of the island of Ireland from the United Kingdom. Many of those who had opposed this process opted to leave the 26 counties after 1922. For those who shared this political perspective, yet opted to remain in the new Irish Free State, the appeal to a court in London represented a real link with a United Kingdom from which they were now excluded. It is also important to recognise that a substantial portion of the population of the Irish Free State did feel uneasy and vulnerable in this new and untested entity. One or both of these considerations ensured that a considerable number, perhaps even a majority, of Southern Protestants did value an appeal to an external tribunal in order to uphold their rights in the last resort. The protests that accompanied the removal of this appeal indicate that these considerations remained relevant more than a decade after the creation of the state. If firmer foundations in cross-community relations were gradually established in the decades that followed, a contention that few would deny, it is important that this signal achievement should not be taken for granted or dismissed as being in some way inevitable. 
